\title{
Aquinas on Our Responsibility for Our Emotions
}

\author{
CLAUDIA EISEN MURPHY
}

U niversity of Toronto

\section{INTRODUCTION}

Philosophical investigations of the concept of responsibility, mirroring its most common function in ordinary language and thought, have been geared for the most part to clarifying intuitionsconcerning moral and legal accountability for actions. But the resurgence of interest in ethical theories concerned with human virtues has resurrected old questions about our responsibility for our character, attitudes, and emotions. The philosophical tradition that takes virtues as a central moral category has taught us to think of virtues not only as involving dispositions to actions, but also dispositions to desires and emotions. It has also taught us to think of actions as only one of the proper objects of moral evaluation, alongside, for example, motives, intentions, beliefs, desires, and emotions. So it is natural that interest in ethical theories concerned with the virtues would yield interest in responsibility for our attitudes and emotions. 1 Thomas Aquinas, who of course is one of the most important architects of the tradition that takes virtues to be central moral categories, holds a ver y complex set of views about our responsibility for our emotions. My aim in this essay is to develop and explain Aquinas's views about whether and when, why, and to what extent we can be responsible for our emotions. I hope to show, in so doing, that his view is plausible, and fits well with some of our own conflicting intuitions about the question.

I owe many important clarifications, distinctions, and corrections to Joseph Goering, Jeff Hause, Bernard Katz, Sean Murphy, and Eleonore Stump. I am also grateful to Scott MacDonald and an anonymous referee for M edieval Philosophy and Theology for further corrections and clarifications. I'm especially grateful to Norman Kretzmann for extremely helpful, subtle, and thorough comments on two different drafts of this essay.

1. Robert Adams has already done much to draw our attention to the different concept of responsibility we are forced to define if we focus on our intuitions about moral accountability for emotions, attitudes, and beliefs, rather than for actions. See R. Adams, "The Virtue of Faith," in Adams, TheVirtue of Faith ( O xford U niversity Press, 1987), pp. 9-24; and "Involuntary Sins," Philosophical Review 94 (1985) : 3-31. I disagree with his account of responsibility for such states, but I am indebted to his illuminating discussions of the topics. 
It seems to me that our intuitions about emotions and their moral evaluation are very unsettled. We sometimes see them as kinds of actions and then, accordingly, tend to think of our responsibility for them in terms of control, avoidability, and the ability to do otherwise. But we also see them as kinds of valuations, closer in nature to volitions and beliefs than to actions; and then we think of our responsibility for them in terms of how they are linked to our character and whether our character was formed freely or compulsively.

Consider, for example, Emma Bovary. She isfull of clearlyreprehensible feelings and attitudes: she detests and despises her husband, she is self-pitying, self-deceiving, and utterly self-centered. It's natural to think that her feelings and attitudes are morally bad, and therefore that she must be responsible for them. But it'll be easier to see how unclear our intuitions are if we take an example of one occurrence of an emotion. One day, after she pushes her young daughter Berthe away in irritation so that the child falls and cuts herself, she is sitting by the child's bed and thinks to herself, with a mixture of indifference and disgust, how odd it is that her daughter is ugly. ${ }^{2}$ If we ask whether she is morally accountable for this emotional reaction (a mix of indifference and disgust), we might look for an answer in evidence about whether she could have avoided it. Might she have avoided the reaction by immediately throwing the thought out of her mind? Might she have devel oped tenderness for the child if she had not given her up to a wet nurse, if she had spent more time with her, concerned with her daily routine? If we decide that Emma might have put the thought away immediately, or that she might have come to love the child had she altered her actions or the regular course of her thoughts, then we might conclude that she is morally accountable for the emotion because she had some degree of control over it.

If, on the other hand, we assume that given Emma's character, there was nothing she could do to make herself feel for Berthe anything but indifference bordering on disgust, we are not forced to conclude that she is not responsible. Rather, we might turn to a different way of thinking about emotions. Even if, given her character and attitudes, she could not have avoided the emotion, we might ask what caused the emotion. Emma's indifference is in large part caused by a self-centeredness so profound that she is unable to notice or be moved by anything about other people except insofar as it affects her own happiness. Thus, because her present emotion iscaused by attitudes and values central to herself, we might conclude that she is responsible for it (as being an expression of herself) even if she could not have avoided it. I nstead of asking whether she could have avoided her disgust with her daughter, we'll ask how she came to develop the more central attitudes of self-centeredness that caused it. We might then ask whether this trait in her character was formed freely or under compulsion by bad treatment she received as a child. And we might conclude that her responsibility for her emo-

2. Gustave Flaubert, M adame B ovary, pt. II, chap. 6. 
tion will depend not on whether she could have avoided the emotion but on whether she is responsible for the character that (inevitably) gave rise to it.

I argue in this essay that both these intuitions about the nature of our responsibility for our emotions are correct, that they can be explained and systematized, and that Aquinas's views on our responsibility for emotions help to do this. It is correct to think that sometimes we are responsible for our emotions just in case we could have avoided them; and also that sometimes we are responsible for our emotions even when we could not have avoided them.

As I argue below, Aquinas's 'passions' are not equivalent to our 'emotions'. But his 'passions' are a necessary component of our 'emotions'. And when he argues that we are responsible for our passions, his argument shows that we are also responsible for other psychological events, which, together with his 'passions', form what we now call 'emotions'. Therefore, I will assume throughout that Aquinas's arguments for the claim that we are responsible for our passions also work as arguments for the claim that we are responsible for our emotions.

Aquinas's account of the passions is an attempt to reconcile two very different views. On the one hand, passions are recognized as the natural and necessary consequences of the fact that the human rational soul is in a body. Viewed in this light, passions are manifestations in a person's sensory, bodily self of her rational evaluative judgments and volitions. As Aquinas puts it, "will cannot be intensely moved to anything without some passion's being aroused in the sensory appetite." $3 \mathrm{O}$ this view, then, passions seem to be integral aspects of the person, the natural expressions of what is most clearly herself: her judgments and volitions. But there is a different view of the passions, one prevalent in both Greek and Christian thought, according to which they are the importation into the rational person of her material or animal nature, with its own source of evaluation and motivation, independent-and sometimes even antithetical to-reason.

Considered in this light, the passions seem to be something foreign to the rational agent, something which, far from being a natural expression of the agent's rational judgments and volitions, can be controlled only extrinsically by the agent's rational self. Aquinas himself symbolizes the tension between these two views by using a different name for the power that is the source of passions according as the passions are understood in the first or the second way. When he considers the passions as the expressions of intellective judgments and volitions in the sensory and bodily aspects of the person, he uses the terms 'irascible and concupiscible powers' to refer to the power whose acts are passions. When he considers the passions as an

3. ST (Summa Theologiae) Iallae 77.6c: " Non enim potest voluntas intense moveri in aliquid, quin excitetur aliqua passio in appetitu sensitivo." All the translations in this essay are my own except for translations of QDM (Q uaestion es Disputatae de $M$ alo) 6, for which I gratefully acknowledge Jeff Hause who was gracious enough to provide me with a translation better than I could produce. 
autonomous sensory and bodily source of valuation, he uses the term 'sensuality' to refer to the power whose acts are passions. ${ }^{4}$

The tension between these two views of the passions is nowhere more apparent than in Aquinas's various discussions of our responsibility for our passions. The first view yields the conclusion that passions are directly voluntary, because directly responsive to our reason and will. 5 The second view, on the other hand, yields the conclusion that we are indirectly responsible for our passions just in case we could have controlled them if we had tried.6 Sometimes, he seems committed to the view that we are often responsible for passionsin this way, because it would be relatively easy for usto control them. ${ }^{7}$ But sometimes, he seems committed to the much more pessimistic view that we cannot control our passionsat all, though we can react to them voluntarily (that is, we can reject them, not interfere, or endorse them). 8

Aquinas doesn't systematically distinguish between his two views of the passions, so the different accounts of our responsibility for our passions he presents are often difficult to piece together. In what follows, I will try to disentangle the different views, and to give what I take to be Aquinas's considered and coherent view of our different levels of responsibility for different kinds of passions.

\section{WHAT ARE PASSIONS?}

Before turning to the question of whether and how we are responsible for our passions, I want to consider briefly what Aquinas thinks passions are. ${ }^{9}$

4. See, e.g., QDV (Quaestiones Disputatae de Veritate) 25.4C: "it is clear that the irascible and concupiscible are subject to reason, as is sensuality; although the name 'sensuality' refers to these powers not insofar as they participate in reason, but in accordance with the nature of the sen sor y part. Thusit isnot as appropriate to say that sensuality is subject to reason as to say this about the irascible and the concupiscible." "Patet quod concupiscibilis et irascibilis subduntur rationi; et similiter sensualitas, quamvis nomen sensualitatis pertineat ad has vires, non secundum quod participant rationem, sed secundum sensitivae partis. Unde non ita proprie dicitur quod sensualitas subditur rationi, sicut de irascibili et concupiscibili."

5. See esp. ST Ia 81.3, ST I allae, 17.7, QDV 25.4.

6. See esp. ST Iallae 17.7c. and ad 1; QDV 25.4 ad 2, ST Iallae 10.3 ad 1 and ad 2.

7. See ST Iallae 24.1, QDV 25.5 ad 5.

8. See esp. QDV 26.6c: "Passions do not belong to the will, either as commanding or as eliciting them, for the principle of passions as such is not in our power. But things are called voluntary because they are in our power." See also ST Iallae 10.3 ad 1, QDM 7.6 ad 6.

9. For an excellent and systematic account of Aquinas's views on the passions as movements of the sensory appetite, see Peter King, "Aquinas on the Passions," in MacDonald and Stump, eds., Aquinas's M oral Theory (Ithaca, NY: Cornell University Press, 1999), pp. 101-32. 
The passions we're interested in here are a species in the broader genus passio. We're interested in passions of the soul, the class in which Aquinas locates what we typically identify as emotions (anger, fear, desire, etc.). In its strictest sense, the word passio means an undergoing, for which the proper philosophical analysis yields the more precise 'alteration': the losing of a property and the acquiring of its contrary. In its strict sense, a passio cannot be in the soul, because alteration can only be in material things and the soul is not material. But it can be in the body (for example, an illness, or a cut), and be perceived by the soul. This sort of passio in the strict sense begins in the body and terminates in the soul as a perception. Even ordinary sense perception can count as a passio in this sense, since it begins with a bodily alteration (something undergone by the sense organ) and ends in the soul's apprehension.

However, there are passions such as anger and fear and the like in the soul, and in their case, the term passio is used much more loosely. Passions of the soul are rightly called passions, or are rightly classified in the genus of passio because (1) they are partly constituted by a bodily alteration suffered passively, 10 and (2) although their psychological constituent, the part of them that is in the soul, is not a genuine alteration (the soul is not capable of being altered), it is nonetheless very much like an alteration, because it involves a disturbance of the rational part of the soul.11 I will hereafter just use passion where the technical term would be psychological passion (as Aquinas himself does throughout the treatise on the passions).

Aquinas defines passions as movements of the sensory appetite. This very classification should be enough for readers of the Summa Theologiae, who, by the time they reach the treatise on the passions in ST Iallae 22, already understand the difference between appetite and cognition, and between the sensory and the intellective appetites and cognition. But Aquinas makes sure to differentiate passions explicitly from (1) cognitive states and events, and from (2) movements of the intellective appetite. 12 The first explicit distinction means that passions are not themselves cognitive states, they are responses to cognitive states. They are attitudes for or against

10. See ST I allae 22.1C.

11. Although Aquinas often criticizes the Stoics' position that all passions are bad because they involve a disturbance, he nonetheless admits that though not all bad, they do all involve a disturbance to the normal functioning of the soul: See ST I allae 44.2 and QDV 26.7 ad 3. In ST Iallae 77.3, he seems to imply that the bodily alteration's disturbing effect on the normal functioning of the powers of the soul is an important reason for holding that there are passions in the soul.

12. For the distinction between passions and cognitive states, see QDV 25.1 "IS sensuality a cognitive or only an appetitive power?" and ST Iallae 22.2 "Are the passions in the appetitive part of the soul rather than in the cognitive part as their subject?" See also ST la 81.1. For the distinction between the sensory and the intellective appetite, see QDV 25.3, 26.3, ST Ia 80.2 , ST I al Iae 22.3. 
objects that have been perceived and construed as good or bad by cognition. Now most contemporar y philosophers interested in the emotion shave argued, and I tend to agree, that 'emotions,' whatever else they involve, involve at least cognitive states. ${ }^{13}$ So Aquinas's passions don't, on their own, constitute emotions. But because it is a necessary condition for the occurence of a passion that there be evaluative cognition of an object, it turns out that Aquinas's passions, taken together with their proximate cognitive cause, make up a complex that could match our understanding of 'emotions'.14 For this reason, although I will translate Aquinas's passio as passion throughout, I will also indicate the way in which his argument applies to our concept of emotions.

The distinction between sensory and intellective appetite is more difficult to grasp than the distinction between appetitive and cognitive states. It is a two-fold distinction:

In any object of appetite two things can be considered: the thing itself which is the object of appetite, and the reason why it is the object of appetite, such as pleasure, or usefulness, or something of that sort.15

The appetite responds to a cognition of an object as possessing something desirable. When cognition presents something to appetite as having certain kinds of properties, the appetite, which is just a pro attitude to the good, is inclined to what is presented as having good-making properties. So there are two aspects to the intentional object of the appetite. The first is just the way in which the object itself is cognized. The second is the kinds of good-making properties the object is presented as having. Commentators have tried to distinguish between the will and the sensory appetite by appealing to the first aspect: sensory cognition and intellective cognition cognize different aspects of the world, and their respective appetites are therefore inclined towards or away from different aspects of

13. See P. Greenspan, Emotions and Reasons (London: Routledge, 1988); R. De Sousa, "The Rationality of the Emotions," in Explaining Emotions, Richard Rorty, ed. (Berkeley: University of California Press, 1980) ; R. Solomon, "Emotionsand Choice," in Explaining Emotions; M. Nussbaum, "Need and Recognition: A Theory of the Emotions," The Gifford Lectures (Edinburgh: University of Edinburgh, 1993); and O akley, M orality and the Emotions (L ondon: Routledge, 1992).

14. I'm grateful to Eleonore Stump for correcting several mistakes I had made in earlier drafts about the relation between passion and emotion. I owe this interpretation to her. Shawn Floyd has recently defended a similar account of the passions against other commentators in "Aquinas on Emotions: A Response to Some Recent Interpretations,"H istory of Philosophy Quarterly 15 (1998) : 161-75.

15. QDV 25.1: "In quolibet appetibili duo possunt considerari: scilicet ipsa res quae appetitur, et ratio appetibilitatis, ut delectatio vel utilitas, vel aliquid huiusmodi." 
the world.16 Sensory cognition is cognition (ranging from perception to memory to imagination to very primitive forms of comparison and inference) of the sensible qualities of particular objects insofar as they can affect the external senses. ${ }^{17}$ Intellective cognition, on the other hand, cognizes common features of particular objects (insofar as they are common), and abstracts them into concepts which can apply to more than one particular thing. So if we distinguish between will and sensory appetite merely on the basis of what objects their respective cognitions are capable of cognizing, sensory appetitive movements or passions will have to be inclinations to non-conceptualized primitive sets of sensor y properties ( my liking this red, sweet-smelling thing), while inclinations to objects that involve any conceptualization (my desire for this apple) will have to be inclinations of the intellective appetite-the will.

But most, if not all of our conscious cognitions are the product of both sensoryand intellective cognition. (I cognize this piece of paper-recognize it as such-by perceiving its senso ry properties, abstracting from them, and applying the appropriate concepts to them.) And therefore, if the distinction between sensory and intellective appetites is a distinction in the objects of their respective cognitions, then the evaluations that count as sensory in human beings will be few and far between, and the inclinations towards objects cognized in such a way even rarer. They will be very primitive reac-

16. R. Roberts, for instance, misunderstands the sensory appetite as a set of instinctive drives that are directed at purely sensory objects. See R. Roberts, "Thomas Aquinas on the Morality of Emotions," History of Philosophy Quarterly 9 (1992) : 287-305. A. Kenny also misunderstands the sensory appetite as a set of attitudes to entirely non-conceptualized particular objects. This leads him to criticize Aquinas since, he argues, we hardly have any attitudes to entirely non-conceptualized objects. Kenny, Aquinas on M ind (London: Routlege, 1993), pp. 59-66.

17. Aquinas's 'imaginatio', which he uses synonymously with the latinized Greek 'phantasia', doesn't have quite the same meaning as our 'imagination'. The sensory cognition includes several powers: the five external senses, as well as a set of internal sensory powers- the inner sense, memory, the cogitative or estimative power, and imaginatio or phantasia. The operation of sensory cognition is completed by the production of a phantasm of the object being cognized. A phantasm, the act of the power of phantasia, consists in the cognized sensible properties of an external object, realized in the matter of the organ of phantasia. Phantasms are then stored in sense memory and can be recalled, combined, or associated in various ways by the interplay of sense memory and imagination ( to yield, for instance, the image of a golden mountain or of a satyr). It is this power of combining phantasms which yields the current dominant meaning of 'imagination'. But the meaning of 'imaginatio' and 'phantasia' is much broader, including such plain 'unimaginative' activities as picturing a dog to oneself upon hearing a bark or the word 'dog', or even plain cognizing of reality. So when I mention the imagination's evaluation of some object or situation, this means merely the sensory cognition's forming a favorable or unfavorable phantasm, on the basis of perception and memory. It should not imply the mind's fabricating anything. 
tions not really worth the attention of a moral philosopher. But Aquinas himself doesn't distinguish the sensory from the intellective appetite by appealing to the object of their respective cognition. Rather, he appeals to the kinds of goodness to which each appetite is inclined, and the way each one is moved:

The higher appetite, which is the will, isinclined directly to the defining characteristic of 'desirability' considered absolutely. For instance, the will isinclined first and principallyto goodness, usefulness, or something like that, but only secondarily to this or that thing, insofar as it participatesin the defining characteristic [ of goodness] .... The lower appetite of the sensory part, which is called sensuality, is inclined to the 'desirable' thing itself, insofar as the defining characteristic of desirability is found in it. I is not inclined to the defining characteristic of desirability itself, because the lower appetite isn't inclined to goodness or usefulness or pleasure itself, but to this useful thing, or this pleasurable thing. 18

Take a particular course of action $r$ : my making a funny but demeaning remark to one of my colleagues in a crowded department meeting. To make $r$ into an object of volition, I will have to produce a reason why $r$ is good. My reasoning may be something like the following: " $r$ will be very pleasurable, pleasure is good, therefore $r$ ought to be done." Because my will just is a pro attitude to the good and a con attitude to the bad, such a reason will move my will, or cause a volition. It is not $r$ itself that causes the volition, it is the reason connecting $r$ to the primary object of my will: the good in general. Because the will, by nature, is an appetite for the good in general, it's open to me to reason about whether the piece of reasoning linking $r$ to goodness is sufficient for the conclusion that $r$ ought to be pursued. For I could conclude that $r$ is indeed pleasurable, but that it's not virtuous. And since I think virtue is a more important good than pleasure, I'll conclude that $r$ is, all-things-considered, bad, despite having some good qualities. In that case, all my reasons taken together will cause me to will against $r$.

The sensory appetite, unlike the will, is not moved by reasons but directly by a certain cognition of particular objects. The cognitions that move the sensory appetite can involve quite a bit of intellective activity, as long as the result is a cognition of a particular thing as having certain

18. QDV 25.1c: "Appetitus autem superior, qui est voluntas, tendit directe in rationem appetibilitatis absolute; sicut voluntas ipsam bonitatem appetit primo et principaliter, vel utilitatem, aut aliquid huiusmodi; hanc vero rem vel illam appetit secundario, in quantum est praedictae ration is particeps. ... Appetitus vero inferior sensitivae partis, qui sensualitas dicitur, tendit in ipsam rem appetibilem prout invenitur in ea id quod est ratio appetibilitatis: non enim tendit in ipsam rationem appetibilitatis, quia appetitus inferior non appetit ipsam bonitatem vel utilitatem aut delectationem, sed hoc utile vel hoc delectabile." 
desirable or lovable (or repulsive or detestable) properties. If I picture $r$ as pleasurable (and this can be as a result of reasoning), then my sensory appetite will immediately be moved to desire to do $\mathrm{r}$. If, on the other hand, I picture $r$ as hurtful to my colleague, my sensory appetite will immediately be moved against doing $r$. If I vividly imagine the pleasure connected with doing $r$, and at the same time tell myself that, all-things-considered, $r$ is bad, I will nonetheless desire (with a sensory appetitive movement) to do $r$ (though I will also will not to). My sensory appetite is not sensitive to general considerations of goodness or badness, it is not responsive to reasons and arguments, but rather it is responsive to predominantly sensory cognitive states through which we cognize particular things as they occur in the world (states of the imagination). It is sensitive to particular properties associated in cognition to a particular object. If the object is cognized as having properties that naturally move the sensory appetite, then the sensory appetite will react directly with a pro or con attitude to the object.

The primary objects of the sensory appetite are sensorily good particular things. The sensory part of a human being includes the body, so things that are good for the body will be sensory goods (health, safety, pleasures associated with the five senses). Sensory goods also seem to include something like the preservation and protection of the ego. So things that promote a good image of one's self-like other people's admiration, or being treated fairly by others, or power over others, or a sense of superiority over others-all seem to count as sensory goods, and therefore as objects to which the sensory appetite is moved naturally.19

But this simple distinction between the will and the sensory appetite is complicated by the fact that Aquinas seems to think the sensory appetite can also be moved by reason. The sensory appetite can also be moved by the judgment of particular reason, which particularizes judgments formed by universal reason, and associates together particular objects and properties ( on the basis of universal reason's judgment). From what Aquinas has to say about the particular reason and its relation to the sensory appetite, it seems that the association of a course of action with the judgment that it is good, is on its own capable of moving the sensory appetite.20 (I discuss the relation between the particular and universal reasons below.) Among prop-

19. Aquinas argues that the vices of pride, anger, vainglory, ambition, cruelty, and curiosity are all vices opposed to the virtues whose subject is the sensory appetite. They are primarily vices of the sensory appetite (unlike injustice, for instance, which is a vice of the will). Although he is careful to say that these vices imply inordinate desire for objects both of sensory and intellective appetite, the fact that he allows that the objects of these vices can be sensory is good evidence that the object of the sensory appetite is not restricted to basic sensory pleasures, as Roberts mistakenly argues. See ST II al Iae 162.3, and 131, 132, 158, 162, 167.

20. Aquinas thinks that in non-human animals, the particular reason is replaced by the estimative power. The estimative power is capable of moving sheep to fear a wolf because of the danger it poses. But dangerousness is not a sensible property of a wolf. So some non-sensible properties can move the sensory appetite 


\section{CLAU DIA EISEN MURPHY}

erties towards which the sensor y appetite is naturally drawn, therefore, are properties which have been judged to be good by the particular reason. For example, upon hearing my colleague say something ambiguous, I daydream about what a funny comment I could make by interpreting his remark in the way he obviously did not intend it to be taken, and begin to form a desire to do $r$. But I immediately see that this would cause him pain, and this association of $r$ with pain to my colleague causes me to stop desiring to do $r$. In this case, it is again a property of $r$ that moves my sensor $y$ appetite, but it does so because I have judged that this property (causing pain) is bad.

It should be clear, therefore, that though there is a difference in the generality of the objects that can move the will and the sensory appetite directly, the difference is not meant to be captured in the distinction between the sensory and the intellective cognition. As long as an object is cognized as a particular thing with properties to which the sensory appetite responds naturally, no matter how much intellective cognition helps to produce it, it will be an object of the sensory appetite. The sensory appetite's natural reaction to certain perceived properties is what yields the conclusion that these properties are attractive or detestable. It is not the judgment that the properties are lovely or detestable that yields the sensory appetite's reaction, although it may be a judgment that alerts the person to the fact that a course of action will be pleasurable, or dangerous. Whether they are good or bad, all-things-considered, is of course a different question (unless the sensory appetite is being moved by particular reason).

Now that I've laid out this distinction between the sensory and the intellective appetite (the will), let me be more precise about what a passion is. Here's as close as Aquinas comes to a definition:

A passion that begins in the soul insofar as the soul is the mover of the body, and has its terminus in the body is called a psychological passion. This is clear in the cases of anger and fear, and others of that sort; for they are aroused by the soul's apprehension and appetite, which are followed by a bodily alteration (transmutatio) 21

in non-human animals. Presumably, therefore, non-sensible properties such as being good or bad, ought to be done or shunned, can also move the sensory appetite in human beings capable of cognizing such properties. Sometimes Aquinas seems to think the particular reason must move the sensory appetite through the mediation of sensible properties and sensory goods (see, e.g., QDV 25.4c, quoted later in this essay). But sometimes he seems to think that particular judgments about what ought to be done are capable on their own of moving the sensory appetite (see ST la 81.3c, quoted later in this essay).

21. QDV 26.2c: "[Dupliciter ergo passio corporis attribuitur animae per accidens. Uno modo. ... Alio modo, ita quod] incipat ab anima, inquantum est corporis motor, et terminetur in corpus: et haec dicitur passio animalis; sicut patet in ira et timore, et aliis huiusmodi: nam huiusmodi per apprehensionem et appetitum animae peraguntur, ad quae sequitur corporis transmutatio." 
So a passion of the soul is a pro or con attitude to a particular object thought to have certain sensible or quasi-sensible properties attractive to sensory appetite. It is aroused in response to a cognition and to appetite-the person's general pro or con attitude to properties of particular objects such as being pleasurable/ painful, useful/ harmful, pretty/ ugly, safe/ harmful, or even good/ bad. O nce the sensory cognition has achieved a construal of the object as, for example, pleasurable or painful, that, together with the person's pro attitude to pleasure or her con attitude to pain (the general nature of her sensory appetite), yields a passion, a pro or con attitude to this particular object. This attitude or passion may range from a mild inclination away from or towards an object, to a strong disposition or motivation for attaining or avoiding the object.22 Finally, a passion is in part constituted by a bodily change which may be perceived as a feeling by the person undergoing the passion, but need not be.

\section{RESPONSIBILITY FOR PASSIONS}

Though Aquinas never directly asks whether passions themselves are voluntary, he asks a number of related questions, out of which I build the following account. 23 Aquinas doesn't clearly distinguish between acts that are voluntary and acts for which we are responsible. He thinks we are morally responsible (or morally accountable) for all and only those acts of ours that are voluntary. Contemporary usage makes the use of 'voluntary' for certain states and acts awkward. It would sound odd if I said that I had voluntarily missed a lecture I very much wanted to attend, because I was negligent in my planning and, as a result, missed the bus. It would be much more natural to say something like: 'It's my fault I missed the lecture.' I think we would agree that if 'it's my fault' then I'm responsible, even though we might hesitate to say that I did it voluntarily.

Aquinas argues that some passions are proper objects of moral evaluation by arguing that they 'obey reason' or 'are subject to command,' properties he takes to be sufficient to establish their moral status. ${ }^{24}$ And

22. Love, for instance, is prior to desire, and therefore not itself a strong inclination to any action with regard to the object. All other passions (aside from hate) involve a desire, and so consist in a more or less intense inclination to act with respect to the object. See ST Iallae 25.1-2.

23. He asks, for instance, whether passions obey reason (ST Ia 81.3, QDV 25.4), whether reason commands passions (ST I al I ae 17.7), whether passions move reason and will (ST I all Iae 9.2, 10.3, 77.1, 77.2), whether passions are proper objects of moral evaluation (ST I al I ae 24.1, 74.3-4, QDV 25.5, 26.6, DM 7.6) , whether passionsincrease or decrease the voluntariness of acts they cause (ST Iallae $6.6,6.7,77.6,77.7$ ).

24. See esp. ST Iallae 24.1 where Aquinas clearly takes his showing that passions 'obey reason' as sufficient evidence for the claim that they are subject to moral evaluation. 


\section{CLAU DIA EISEN MURPHY}

since he maintains that moral evaluation is appropriate only when the agent is responsible for the action or state of affairs being evaluated, the conditions which he takes to be sufficient for moral evaluation are sufficient for responsibility. 25 So when he argues that the passions satisfy those conditions (in one way or another), I take him to be arguing implicitly that we are responsible for our passions.

Throughout the many texts in which he takes up these issues, Aquinas is fairly consistent about the following explanations:

The lower appetites, that is, the irascible and the concupiscible, are subject to reason in three ways.

(1) First, of course, in connection with reason itself. For since the same thing considered under different descriptions, can be made either pleasurable or horrible, reason proposes to sensuality, through the mediation of imagination, some thing under the aspect of a pleasurable or a sad thing, in accordance with the way it seems to reason, and thus sensuality is moved to joy or sadness. . . .

(2) Second, in connection with the will. For in human beings, powers that are connected and ordered to one another [are such that] an intense movement in one of them, and more especially one that is higher, overflows in the other. That's why, when the movement of the will, through a choice, is focused on something, the irascible and concupiscible follow the movement of the will. ...

And in this way, it's clear that the irascible and the concupiscible are subject to reason, as well as sensuality. ${ }^{26}$

Aquinas always divides what he has to say about the passions' being subject to the rational part into at least the two categories described above: the passions are subject to the rational part insofar as they are responsive to reason; and the passions are subject to the rational part insofar as they are in the control of the will. H owever, Aquinas's own explanations of these forms of control vary greatly. For instance, sometimes, as in the passage above, the will is said to control the passions because they overflow from an intense movement of the will, whereas in different passages, the will is said to control the passions because no external action follows directly from a passion with-

25. See, e.g., ST Iallae 6.2 ad 3.

26. QDV 25.4C: "Subduntur autem appetitivae inferiores, scilicet irascibilis et concupiscibilis, rationi, tripliciter.

Primo quidem ex parte ipsius rationis. Cum enim eadem res sub diversis conditionibus considerari possit, et delectabilis et horribilis reddi, ratio opponit sensualitati mediante imaginatione rem aliquam sub ratione delectabilis vel tristabilis, secundum quod ei videtur; et sic sensualitas movetur ad gaudium vel tristitiam. ... .

Secundo ex parte voluntatis. In viribus enim ordinatis ad invicem et connexis ita se habet, quod motus intensus in una earum, et praecipue in superiori, redundat in aliam. Unde, cum motus voluntatis per electionem intenditus circa aliquid, irascibilis et concupiscibilis sequitur motum voluntatis. 
out the consent of the will.27 Moreover, since volitions are for the most part just appetitive responses to the judgment of reason, the two are rather too closely connected to distinguish different forms of control on the basis of the distinction between reason and will. It seems to me, in light of Aquinas's own carelessness about his categories, and in light of the categories' tendency to collapse into one another, that hisviews about our responsibility for passions are best divided along different lines, which I set out below.

Passions are subject to the rational part of the soul (both reason and will) - that is, we are responsible for our passions- because they are capable of being affected by reason and will in different ways. It seems to me that Aquinas describes two broad ways in which passions are capable of being affected by reason and will: externally — when a passion is al ready occurring, it can be affected by reason and will-and internally-when reason's or will's activity gives rise to a passion. Both internal and external capacities for being affected yield responsibility for the passion.

In the passage cited above, the passions' being subject to reason (1) seems to fit both categories. They are subject to reason externally, because, given the power of reason over the imagination, and the importance of the imagination as providing a passion with itsobject, reason can affect (intensify or cal $\mathrm{m}$ ) a passion that isal ready occurring. But they are al so subject to reason internally, because reason's forming a judgment is likely to affect the imagination and therefore to elicit a passion in response to the imagined object.

The passions' being subject to the will (2), on the other hand, seems to fit only the category of passions' being subject to reason internally. The will's activities somehow, through some mysterious psychological connection, yield passions of various sorts.

So on the one hand, we are responsible for our passions in case they are responsiveto reason, in case once they occur, reason can al ter and affect them. I'll call this explanation of responsibility for our passion the explanation in terms of extrinsic control. On the other hand, we are responsible for our passions in case they are themsel ves responses to reason or the will, in case they occur because of the activity of reason and will. I'll call this explanation of responsibility for our passions the intrinsic account of responsibility.

\section{THE INTRINSIC ACCOUNT OF RESPONSIBILITY}

Aquinas's intrinsic account of our responsibility for our passions involves two claims: that passions can be aroused spontaneously by a reasoned judgment or a volition, and that this constitutes a sufficient condition for our being responsible for those passions. 28 It seems clear to

27. See, e.g., ST la 81.3.

28. I use 'reasoned' to avoid the evaluative 'rational', which I save for cases in which reason has judged correctly, not for cases in which reason has merely produced a judgment. 
me that he holds these two views from the following passage (and others like it).

The irascible and concupiscible powers [ the powers whose acts are passions] obey. . . reason as regardstheir veryacts. The reason for thisisthat the sensory appetite in other [non-human] animals is naturally moved by the "estimative" power-as when, for instance, a sheep estimates that a wolf is an enemy and fears it. But ... in place of the estimative power, a human being has the cogitative power, which some call the particular reason because it associates together individual impressions. That's why the sensory appetite in a human being is naturally suited to be moved by the particular reason. The particular reason itself, on the other hand, is naturally moved and directed in accordance with universal reason. . . . Therefore, it's clear that the universal reason commands the sensory appetite- which is distinguished into the concupiscible and the irascible [ powers] — and so the appetite obeys it. . . . Anyone can experience this in himself. For by applying some universal considerations, he can calm his anger or fear, or anything of the sort; or he can also arouse them. 29

The examples of anger and fear at the end of the passage seem to me to be misleading. They suggest that the long explanation of the influence of reason on passion is merely meant to explain why the passionsare responsive to reason in an extrinsic way. In the anger example, one is angry before she formsa judgment about the situation, and then, upon forming some general judgment, she can calm her anger because it is responsive to reason. This suggests that Aquinas is describing an extrinsic account of responsibility: we are responsible for our passions because they can respond to reason. But the long description of the way in which the universal reason influences the particular reason ( presumably, a judgment that course of action c is bad will yield an association in imagination of $c$ with some property hated by the person's sensory appetite), and the particular reason governs the imagina-

29. ST Ia 81.3c: "Irascibilis et concupiscibilis obediunt superiori parti, in qua est intellectus sive ratio et voluntas, dupliciter: uno modo quidem, quantum ad rationem; alio vero modo, quantum ad voluntatem.-Rationi quidem obediunt quantum ad ipsos suos actus. Cuius ratio est, quia appetitus sensitivus in aliis quidem animalibus natus est moveri ab aestimativa virtute; sicut ovis aestimans lupum inimicum, timet. Loco autem aestimativae virtutis est in homine, sicut supra dictum est, vis cogitativa; quae dicitur a quibusdam ratio particularis, eo quod est collativa intentionum individualium. Unde ab ea natus est moveri in homine appetitus sensitivus. Ipsa autem ratio particularis nata est moveri et dirigi secundum rationem universalem: unde in syllogisticis ex universalibus propositionibus concluduntur conclusiones singulares. Et ideo patet quod ratio universalis imperat appetitui sensitivo, qui distinguitur per concupiscibilem et irascibilem, et hic appetitus ei obedit.-Et quia deducere universalia principia in conclusiones singulares, non est opus simplicis intellectus, sed rationis; ideo irascibilis et concupiscibilis magis dicuntur obedire rationi, quam intellectui.-Hoc etiam quilibet experiri potest in seipso: applicando enim aliquas universales considerationes, mitigatur ira aut timor aut aliquid huiusmodi, vel etiam instigatur." 
tion and the sensory appetite, seems to me to show that passions can be not only responsive to reason, but also responses to reason's judgment. Reason forms a judgment which automatically gets translated into an object accessible to the sensor y appetite, and gives rise to a passion that isa response to the judgment. The examples at the end of the passage seem to me to point to cases where the influence of reason on the passion is obvious because it is consciously elicited. But the passage itself seems to commit Aquinas to the view that many passions are just organically or intrinsically dependent on a judgment of reason for their object.

In fact, the passage might seem to suggest that all passions are responses to reasoned judgments, because here Aquinas is focusing on reason as a source for the objects of the sensory appetite. If a person is responsible for a passion when the passion is somehow dependent on reason, and if all passions, by their very nature, are always caused by reasoned judgments through the mediation of the particular reason, then we are responsible for all passions. This, of course, would not be a very attractive view, and it is not the view Aquinas accepts. Aquinas holds that although the sensory appetite can be moved by reason (in the way described above), it can also be moved by its own source of cognition:

The sensory appetite is naturally suited to be moved not only by the estimative power in non-human animals and the cogitative powerwhich is guided by universal reason-in human beings, but also by the imagination and the sensory [ cognition]. 30

Therefore, Aquinas cannot hold that all passions are caused by a reasoned judgment. He holds, rather, that when they are caused by a reasoned judgment, we are responsible for them in the intrinsic way, whereas when they are caused by the imagination and the sensory cognition, if we are responsible for them at all, it will have to be in a different way: that is, because they could have been controlled by reason'sinfluence, because they are constitutionally responsive to reason.

In what follows, I will call passions that are responses to judgments of particular reason or to volitions 'reason-dependent passions', and ones that are responses to sense and imagination 'reason-independent passions'.

In connection with Aquinas's argument that we are responsible for our reason-dependent passions I will examine the following two questions:

(1) What is the relationship between reason-dependent passions and reasoned judgments?

(2) What does reason-dependence have to do with responsibility for passions?

30. ST Ia 81.3 ad 2: "N atus est enim moveri appetitus sensitivus non solum ab aestimativa in aliis animalibus, et cogitative in homine, quam dirigit universalis ratio; sed etiam ab imaginativa et sensu." 


\section{(1) Reason-dependence}

Aquinas seems to accept two forms of reason-dependence:

A passion of the lower appetite can follow from something apprehended by the intellect in two ways. [1] In one way insofar as that which is understood by the intellect as a universal is represented in the imagination as a particular thing. And in this way the lower appetite is moved-e.g., when a believer accepts with his intellect the intelligible notion of future punishments and forms phantasms of them by imagining the fire burning, the worms gnawing, and other things of that sort, from which there follows the passion of fear in the sensory appetite. [2] In another way, insofar as the intellective appetite is moved by an intellective cognition, from which, by some sort of overflow (redundantia) or command, the lower appetite is moved along with it. 31

(1) When an agent consciously produces a certain evaluative construal of an object or situation in imagination as a representation of a general evaluation, then the passion that follows will be dependent on reason and will in an obvious way: it will be caused by a judgment or volition as an object of the judgment or the volition. If I will to grieve properly for the victims of some distant disaster, I may consciously picture their plight to myself, or imagine what it would be like to be one of them. I will then have an imaginative construal of their situation likely to elicit a response from my sensory appetite-I associate in my imagination properties capable of moving my sensory appetite with the right object. If I succeed in producing pity or compassion, it will be reason-dependent: it will have been caused by reasoning and willing with it as an object. In such a case, the reason-dependent passion is not produced spontaneously in response to some object of intellect, but is produced consciously in response to a reasoned judgment accompanied by a volition to have such a passion.

But of course, passions of type (1) need not be consciously produced, they may arise directly as a result of the person's naturally translating a general judgment into a particular case, and forming a construal of the situation suitable for a reaction from the sensory appetite without consciously willing to do so. When the passion arises thus spontaneously, passions of type (1) seem to me barely distinguishable from passions of type (2). Since all acts of will are based on judgments of reason, a passion of type (2) will depend not only on a volition but on the judgment of reason

31. QDV 26.3 ad 13: "Ex aliquo apprehenso per intellectum potest sequi passio in appetitu inferiori dupliciter. [1] uno modo in quantum id quod intelligitur universaliter per intellectum, formatur in imaginatione particulariter, et sic movetur inferior appetitus; sicut cum intellectuscredentis accipit intelligibiliter futuraspoenas, et earum phantasmata format imaginando ignem urentem et vermen rodentem et alia huiusmodi, ex quo sequitur passio timoris in appetitu sensitivo. [2] alio modo in quantum ex apprehensione intellectus movetur appetitus superior, ex quo, per quandam redundantiam vel imperium, appetitus inferior commovetur." 
upon which the volition depends. 32 As far as I can see, a passion that follows on a volition through overflow is no different than a passion that spontaneously arises on the basis of a reproduction of a reasoned judgment in imagination. ${ }^{33} \mathrm{~A}$ passion $\mathrm{p}$ about an object 0 is reason-dependent, then, when it arises, either deliberately or spontaneously, in response to reason's deliberation and judgment, and will's volition. The judgment and volition may have $p$ as an object, or they may have only 0 as an object.

To clarify the ways in which passions can be reason-dependent, consider the following example. I am with my daughter at a crowded picnic, when I feel something wet and sticky on my leg. I immediately look down with some alarm at the thought that some mollusk or insect may be crawling on me, to discover instead that my daughter is clinging to my leg and skirt with her very dirty hand. I immediately feel angry at the thought that I will have to get the skirt dry cleaned and that I have told her many times not to touch my clothes with dirty hands. But then I remember that she's very shy in unfamiliar situations, and that she's reassuring herself by keeping in physical contact with me, and, as a consequence of these obser vations, I feel a great protective tenderness that takes the place of my anger.

There are at least three different passions to be investigated in this little story: my alarm, my anger, and my tenderness. The first one probably does not require any activity of reason: my sensor $y$ appetite reacts immediately to the perception of un pleasant and unexpected sensations. But perhaps I form a slightly more complicated reaction, thinking very quickly of what might be producing this sensation, I assume it must be a very large insect or mollusk, and then feel disgust. This passion requires some activity of reason for the production of a hypothesis about what might be touching me. But asI argued above, this is a common feature of most of our passions. Because almost all conscious cognitions in human beings are the result of both sensory and intellective cognition, almost all passions are responses to cognitions that are in part produced by reason. If that's the case, it makes no sense to differentiate between reason-dependent and reason-independent passions on the ground that the first are in part the product of intellective cognition and not the other. So my reason's role in producing my disgust is not sufficient to make it reason-dependent.

32. One might suggest that the difference between spontaneous passions of type (1) and passions of type (2) is that whereas spontaneous passions of type (1) have an object translated from a reasoned judgment to something accessible to the sensory appetite, passions of type (2) are just caused directly by a volition, without any object in sensory cognition. But since a passion of the soul is defined as a movement of the sensory appetite in response to sensory cognition, such a movement of sensory appetite would not be a passion.

33. Perhaps the emphasis on the will in passions of type (2) is meant to underscore a connection with external action (when I will intensely do to $x, I$ naturally experience a passion directed to $x$ ), whereas the emphasis on reason in type (1) underscores the fact that there need not be a volition for action to produce a reason-dependent passion (the person who, upon imagining the torments of hell begins to be afraid, is not willing a particular action). 
My anger requires some activity of reason, not only in producing a cognition of an object, but also in evaluating it. It is as a result of reasoning that I know that my skirt's being dirty means I will have to dry clean it, and that I conclude that I ought to punish my daughter, who intentionally (she's been warned many times) brought about something bad. In this case, the involvement of reason is no longer just at the level of cognition, but at the level of conscious reasoning and evaluation. I think, however, that this involvement of reason doesn't necessarily yield reason-dependence in the passion. As I've described the case, my anger is not based on the final judgment of my reason. It is based on a preliminary evaluation of the situation which I do not yet endorse. I notice the greasy stain on my skirt, think about what removing it will entail, remember that this has happened many times already and that I've warned my daughter against doing it again, and conclude, tentatively, that she has intentionally wronged me. I don't commit myself to this conclusion yet, however, because I have not thought about what else might be relevant. 34

There are two reasons for thinking that being a response to preliminary judgments of reason does not make passions reason-dependent. The first is that Aquinas usually associates reason-dependent passions with volitions (they 'overflow' from a strong volition, or are commanded by reason and will). But volitions are not responses to preliminary reasoning about an object, but to final conclusive judgments. If I judge conclusively that my daughter ought to be punished, I am judging that punishing her is just, pedagogical, and therefore good. I am committing myself to that judgment. When I judge in a tentative, preliminary way that she should be punished, I 'm judging that perhaps, if nothing else is relevant to the case, she ought to be punished. M yfinal judgment, not my preliminar yand tentative judgment, will yield a volition. Therefore, it is natural to suppose that a reason-dependent passion must be dependent on a final, not a tentative, judgment.

The second reason for thinking that a passion that is caused by a tentative judgment of reason is not reason-dependent is that Aquinas often calls reason-dependent passions, passions that are caused by a judgment of reason, 'passions that follow the judgment of reason.' 35 But the judgment of reason is its final judgment, the judgment to which the agent is committed, not a preliminary tentative conclusion. Passions that precede the judg-

34. Although I am claiming that the anger in this example is not reason-dependent (i.e., is not caused by a judgment of reason or a volition), it's clear, as Scott $\mathrm{MacDonald}$ has pointed out to me, that since the anger is responsive to reason, I am responsible for it (or would be if it persisted). I will be discussing such external forms of control over passions in the second half of the essay.

35. Aquinas argues in a series of passages where he mentions 'passions consequent to the judgment of reason' that these passions are subject to the fullest kind of moral evaluation. They are sinful and blameworthy when bad and meritorious and praiseworthy when good. Therefore, it seems to me not to stretch the text too much to identify reason-dependent passions to passions consequent to the judgment of reason. See, e.g., ST I all ae 77.6c and ad 2, Iall ae 24.3 ad 1 and ad 3, Ial Iae 59.2, QDV 26.7, QDM 3.2. 
ment of reason may be dependent on data the agent considers while deliberating, before she comes to a conclusion. And such passions are not reason-dependent. This is perhaps what Aquinas means when he repeats Aristotle's judgment about anger: "anger hears reason to some extent, insofar as it denounces the injury done to it, but it does not listen perfectly' because it does not observe the rule of reason in determining a punishment." 36 Anger is only elicited by considerations of reason:

Anger is the appetite for revenge. But [the notion of] revenge implies a comparison between the punishment to be inflicted and the harm done to oneself. ... But to compare and to draw a conclusion are acts of reason, and therefore, anger in some way requires reason (est cum ratione). 37

But it tends not to wait for reason's final judgment, but to get aroused by tentative preliminaryjudgments, and so it tends not to be reason-dependent.

So it is only my third passion, my protective tenderness, which is caused by my final, endorsed judgment that, despite the small infraction, my daughter ought to be cared for and protected because of her shyness, that is reason-dependent. $38 \mathrm{~A}$ reason-dependent passion, then, is one that is caused by a final judgment of reason. But being caused by such a judgment can't be sufficient for reason-dependence. I magine that my final judgment that my daughter ought not to be scolded but treated tenderly causes me to think vividly of the annoyance of my dirty dress, so that I get angry. 39 Clearly my anger is not reason-dependent, even though it has been caused by my final judgment.

What differentiates the case in which I feel anger at my daughter from the case in which I feel tenderness is the relation between the propositional content of the reasoned judgment and that of the evaluation that is the proximate cause of the passion. Aquinas draws a distinction between per se and per accidens relations between a passion and a volition: a passion is related to the will per se "when the passion excites the will to what is like itself, as when the will is inclined by sensory desire to consent to the desired

36. ST Iallae 46.4 ad 3: "'I ra audit aliqualiter rationem sicut nuntiantem quod iniuriatum est ei; sed non perfecte audit,' quia non observat regulam rationis in rependendo vindictam." See Aristotle, Nicomachean Ethics, vii.6.

37. ST Iallae 46.4c: "I ra est ap petitus vindictae. H oc autem collationem importat poenae infligendae ad nocumentum sibi illatum . . . Conferre autem et syllogizare est rationis; et ideo ira est quodammodo cum ratione."

38. Of course, this tenderness could be described differently, as a semi-instinctive maternal feeling that is not a response to a final reasoned judgment. If my final judgment supported anger, I might feel the pull of tenderness tempering my anger. But in this example, I'm assuming that this is not the case. The tenderness only arises as a response to a reasoned judgment about the nature of the situation.

39. I'm grateful to Bernard Katz for pointing this possibility out to me (of course he gets it from Davidson, "How is Weakness of the Will Possible?" in Essays on Actions and Events [Oxford: Clarendon Press, 1980]). 
object, or by anger to will revenge"; it is related to the will per accidens when instead of provoking the will to something like itself, it provokes it to its contrary by giving the will the occasion to disapprove of the passion. 40 As Aquinas describes the relation here, it's the passion that's causally influencing the will either per se or per accidens. But the distinction should hold also when the causal relation is reversed. The per se relation between the passion and a volition is one of similarity, where the attitude in the passion is like the attitude in the volition. Whereas the per accidens relation is one of incompatibles, where the content of the passion is incompatible with the content of the volition. A reason-dependent passion is one that is related to the corresponding volition per se rather than per accidens.

The cognitive source of the likeness in attitudes (in the sensory appetite and the will) must be something like a relation of particular to general judgment. In a case where my passion is per se related to my volition, the judgment produced by my particular reason (the proximate cause of the passion) is a particularization of the judgment produced by my reason (the proximate cause of my volition). That's why the reaction of my will to my deliberated judgment and the reaction of my sensory appetite to the judgment of my particular reason are alike: because they are responses to judgments that are different only in their generality. My deliberated judgment is a judgment that a certain course of action is good overall or ought to be done, and it moves my will because of my will's natural inclination to the good. My particular judgment is an association of an object or course of action with a property that naturally moves the sensory appetite, among which is the property that it's been judged by reason to be good, or to be done. So if the judgment of my reason is that it would be best to nurture my daughter's self-confidence by being lenient and protective, then the judgment that right here and now I should gently remove her hand from my skirt and keep it in my hand (rather than scolding her) is related to the judgment of reason as particularizing it. When my reasoned judgment that my daughter ought not to be scolded yields anger that she dirtied my skirt, the propositional content of the proximate cause of my anger is incompatible with that of my final judgment that she ought not to be scolded. My tenderness is related per se to my judgment, whereas my anger is related to it only per accidens. A passion is reason-dependent, then, when it is related per se to a volition, that is, when the evaluative cognition that is the proximate cause of the passion is a particularization of the deliberated judgment of reason. When the relation is only per accidens, the passion is not dependent on the volition to which it is related only per accidens (it may of course be related per se to a different reasoned judgment, in which case it will be reason-dependent) .

40. QDV 26.6c: "Per se quidem, quando passio excitat voluntatem ad id quod est sibi consimile, sicut cum ex concupiscentia voluntas inclinatur ad consentiendum concupiscibili, ex ira ad volendum vindicat." 
A reason-dependent passion, then, is one that is psychologically caused by a reasoned judgment or a volition, in such a way that the judgment of particular reason is a particularization of the reasoned judgment, and the attitudes produced by each judgment respectively in the will and the sensory appetite are alike. 41

The causal explanation of what makes a passion reason-dependent seems to fit most of the cases of such passions Aquinas describes. But he also seems to think passions can be reason-dependent even when they are not caused by a judgment of reason. This further account of reason-dependence will be important for understanding some of what Aquinas has to say about extrinsic control over passions, so I will briefly consider it here.

The passions of the soul can be consequent to the judgment of reason ( one of Aquinas's ways of describing reason-dependent passions) in two ways:

In one way, through overflow. . . In the other way, through choice-I mean when a human being chooses, on the basis of reasoned judgment, to be affected by some passion, so as to act more promptly, with the cooperation of the sensory appetite. 42

What is being described here, it seems to me, is not another case of a reasoned judgment causing a passion. Choosing to be affected by a passion is not choosing to elicit a passion, but rather choosing that an already occurring passion should have its full effect on oneself, because one endorses or approves of the passion. The relation between the reason-dependent passion and the reasoned judgment is therefore not causal in this case, since the passion predates the reasoned judgment. Rather, in this case, the passion is reason-dependent because it is the object of an approving or endorsing judgment from reason, and of an endorsing volition from the will. So passions can be reason-dependent either by being caused by a reasoned judgment, or by being the object of an endorsing judgment and volition.

41. It follows from this definition that only rational passions (that is, passions that are in accordance with the person's reasoned judgments) are reason-dependent. But it does not mean that I can't judge a reason-dependent passion of mine to be irrational and fight against it. For we sometimes waver between incompatible judgments of things, and one of these judgments could give rise to a reason-dependent passion which reason ultimately repudiates. Sometimes reasoned judgments are not fully conscious, so I may have a reason-dependent passion caused by a somewhat unconscious reasoned judgment and a fully conscious reasoned judgment repudiating it. I will have more to say about this matter in the conclusion.

42. ST Iallae 24.3 ad 1: "Passiones animae dupliciter se possunt habere ad iudicium rationis. U no modo, antecedenter. . . . Alio modo se habent consequenter. Et hoc dupliciter. Uno modo, per modum redundantiae: quia scilicet, cum superior pars animae intense movetur in aliquid, sequitur motum eius etiam pars inferior. Et sic passio existens consequenter in appetitu sensitivo, est signum intensionis voluntatis. Et sic indicat bonitatem moralem maiorem.-Alio modo, per modum electionis: quando scilicet homo ex iudicio rationis eligit affici aliqua passione, ut promptius operetur, cooperante appetitu sensitivo." 
Although I will return to passions that are reason-dependent through endorsement in my discussion of extrinsic control over passions, my discussion of intrinsic control over passions will focus exclusively on passions that are reason-dependent through being caused by a reasoned judgment.

Of course, none of this shows that all passions are reason-dependent: imagination and sensory cognition can form evaluations that do not depend on reasoned judgments. I am not compelled to undertake any reasoned examination of the data or to form a final judgment of the situation. When my daughter dirties my skirt, I can immediately react with anger, without stopping to think whether there are extenuating circumstances, without deliberation or reasoned judgment. But it shows that some passions are reason-dependent, and the following argument about responsibility applies to them.

\section{(2) H ow D oes Reason-dependence Make U s Responsible for Our Passions?}

$\mathrm{H}$ aving defined reason-dependent passions, I turn to my second question: how does showing that passions are reason-dependent in this way have any tenden cy to show that we are responsible for our passions or our emotions? Aquinas identifies two different ways in which we can have control over our own acts:

We are masters of our actions by our will. Not only those actions that are immediately elicited by the will, such as liking and wanting, but those that are commanded by the will and elicited through other powers, such as walking, talking and other such acts. ${ }^{43}$

Acts which are proper objects of moral evaluation-that is, acts for which we are responsible-are all and only those over which we have control.44 So it follows that we can be responsible for two sorts of acts: (1) actsthat are themsel ves acts of will (choosing, wanting, intending), or (2) actsthat are caused by these acts of will in the right way. Aquinas's discussion of comman ded acts is complex and seems to cover two different cases. If I decide to walk to the pool right now to go for a swim, my getting up, gathering my swimming gear, and walking to the pool will all count as commanded acts of will. They are commanded by the will because they are caused by a choice, and are the object of the choice. So an act A2 counts as a commanded act of

43. QDV 26.6c: "Sumus autem domini nostrorum actuum per voluntatem: non solum illorum qui immediate ex voluntate eliciuntur, ut diligere et velle, sed eorum qui a voluntate imperantur per alias potentias eliciti, ut ambulare, loqui, et huiusmodi."

44. See ST Iallae, prologue, and 6.3sc. "That over which we are masters is said to be voluntary." 
will if an elicited act of will A1 (for example, commanding or choosing), with A2 as its object, causes A2's coming about (and I assume that A1's causing A2's coming about implies that if $A 1$ had not occurred with $A 2$ as its object, given the same set of circumstances, then $A 2$ would not have occurred either). I'll call this form of command conscious command.

But Aquinas's analysis of commanded acts of will seems also to include acts that follow from elicited acts of will without being the objects of the act of will. For instance, Aquinas sometimes describes the sort of passion that follows an intense act of will by overflow (redundantia) as commanded. 45 But such passions, though theyare caused byajudgment of reason and a volition, are not caused as being the object of the act of will, but as sharing the same object with the act of will. So an act A2 with 0 as its object is a commanded act of will when an elicited act of will A1 with 0 as its object causes A2's coming about. I'll call thisform of command unconscious command.

Aquinas argues that the passions are subject to the will's command, and he seems to think they are subject to both conscious and unconscious command. When the devout person wills to elicit in herself religiously appropriate passions about hell, she acts on her imagination with the conscious project of forming a certain passion. And so her passion (if it indeed occurs, and is caused by her willing in the right way) is voluntary because it is caused by an act of will with this passion as its object-it is voluntary as an act consciously commanded by the will. But more often, when Aquinas argues that passions obey reason or will, he clearly does not have this paradigm in mind. When a passion is reason-dependent in the wayl've outlined above, it is caused bydeliberated judgment and volition with not the passion itself, but the object of the passion as its object. So most reason-dependent passions are not consciously but unconsciously commanded by the will.

It's quite clear how consciously commanded acts are voluntary; in fact, they are paradigms of the voluntary. But it is less clear how unconsciously commanded acts are voluntary, or how we are responsible for them. After all, it's clear how we are in control of the things we consciously will to do; but it's less clear how we're in control of things that are caused by acts of the will without our willing them. Aquinas seems to think that we are somehow more responsible for unconsciously commanded than for consciously commanded acts:

The closer any of the other powers are to the will, the more they participate in its movement. That's why the lower appetitive powers themselves obey the will with regard to their principal acts, as being closest to it. 46

45. See, e.g., QDV 26.3 ad 13.

46. QDV 25.4: "Tanto autem unaquaeque aliarum virium plus de motu eius participat, quanto fit ei propinquior. Unde ipsae appetitivae inferiores voluntati obediunt quantum ad suos principales actus, utpote ei propinquissimae." 
Presumably, the sensor y appetite is closer to the will than, for example, the power of moving the external limbs, because like the will, it is an appetitive power. If we are responsible for the movements of the will themselves, which are reactions to intellective judgments, then it seems probable that we will be responsible in the same way for movements of the sensory appetite that are responses to reason-dependent evaluations (that is, to evaluations that are themselves caused by intellective judgments). So our responsibility for unconsciously commanded acts of will should be similar to our responsibility for elicited acts of will.

We are responsible for elicited acts of will because they are in the agent's power, that is, because they are caused by a combination of reasoned judgments and the person's structure of ends which are themselves free. Aquinas's view of the nature of freedom and its connection with responsibility is very complicated, and I can't do it justice in this short section of the paper. But here are the main elements of his view.

A human being chooses (an elicited act of will) freely when it is possible for her either to choose other wise or, at the very least, not to choose as she does. 47 Now the will can be inclined to (or choose) only things which reason judges to be good. Therefore, saying that a human being chooses freely, that is, saying that she could either choose otherwise or abstain from choosing altogether, means that she is able to judge the object or course of action under consideration as good (she has a reason for choosing it), but that she can also judge the object or course of action as not good, or at least that she can judge her act of choosing as not good (she has a reason for not choosing it, or for choosing otherwise). Freedom of choice, then, reduces to something like freedom of judgment about what ought to be done or pursued. We lack such freedom of judgment when an object is such that we cannot but judge it to be good. "If something isapprehended asa good which is suitable with regard to all the particulars that can be considered, it moves the will necessarily [as long as it is considered]. "48 But, since something that is good in this way can only be an ultimate end, and choice is only about the meansto an already desired end, Aquinas dismisses this kind of case as never posing a problem for free choice.49 $\mathrm{O}$ the other hand, we have freedom of judgment when the object is itself not perfect:

If a good is of such a sort that it is not found to be good with regard to all the particulars that can be considered ... . one will be able to will an alternative to it, even while thinking about it, because presumably, [this

47. See ST Iallae 13.6.

48. QDM 6c: "Si ergo apprehendatur aliquid ut bonum conveniens secundum omnia particularia quae considerari possunt, ex necessitate movebit voluntatem."

49. Examples of such objects which, while being considered, cannot but be willed are happiness and union with God, both of which are only apprehended as perfect goods when they are apprehended as ends. See ST Iallae 13.6. 
alternative] is good or suitable with respect to some other particular which one has considred. 50

Elicited acts of will are free, then, when the judgments that give rise to them are free. What does it mean for judgments to be free? So far, we have seen that a judgment about an object or course of action $c$ is free if the person judging can judge that $\mathrm{c}$ is good and that $\mathrm{c}$ is not good, or at least that c isgood and that choosing c is not good (for example, at this moment). This will enable the person choosing to preserve her ability to choose differently or at least not to choose at all. What is supposed to guarantee this freedom of judgment is that the object or course of action being chosen, or the choice itself, is not good under all descriptions, but rather has some bad aspects. Therefore, what freedom of judgment seems to amount to is the ability to see and be influenced by the good and bad aspects of the particular object or course of action. This implies at least the ability to cognize and react to relevant properties of the object or course of action. Aquinas seems to think that in case someone's values and structure of ends is mistaken, it al so requires the ability to alter these ends and values, though he does not seem to think this ability is necessary when someone's values and ends are not mistaken. 51

What guarantees that all human beings have such freedom of judgment is that all human beings have the ability to deliberate about objects and actions and their own judgments. 52 Because we have the ability to deliberate, we can see and weigh the good and bad features of things, actions, and judgments. Because we have the ability to deliberate, we can revise our bad values. All rational agents have the ability to deliberate and to come to the (or one of the) correct decision. All rational agents, when theyform an intention

50. QDM 6c: "Si autem sit tale bonum quod non inveniatur esse bonum secundum omnia particularia quae considerari possunt, non ex necessitate movebit etiam quantum ad determinationem actus, poterit en im al iquisvelle eius oppositum, etiam de eo cogitans, quia forte est bonum vel conveniens secundum aliquod aliud particulare consideratum, sicut quod est bonum sanitati, non est bonum delectationi."

51. See, e.g., ST Iallae 19.6 ad 3, ST Iallae 78.2c, where Aquinas insists that someone with mistaken or vicious values is al ways able to alter them. As Eleonore Stump argues very convincingly, Aquinas is also committed to the view that, for example, the blessed in heaven choose freely though they are incapable of altering their values and sinning. See Stump, "Intellect, Will, and the Principle of Alternate Possibility," in Christian Theism and the Problems of Philosophy, Beaty, ed. (South Bend, In: University of Notre Dame Press, 1990). This asymmetry in the requirements for responsibility in people with good values and in those for people with bad ones recalls Susan Wolf's views. See Wolf, "Asymmetrical Freedom," in M oral Respon sibility, Fisher, ed. (Ithaca, NY: Cornell University Press, 1986). And Wolf, Fredom Within Reason (Oxford: Oxford University Press, 1990).

52. See QDV 24.2 on free choice or judgment's consisting in the ability to judge one's own judgments. See also Scott MacDonald, "Aquinas's Libertarian Account of Free Choice," in Revue Internationale de Philosophie 52 (1998). 
or choice (elicited acts of will), are responding either to deliberation or to considerations that would have been sensitive to deliberation. 53

We are in control of our elicited acts of will, then, because they are caused by free judgments ( judgments that are or could have been the result of free deliberation, and a set of attitudes and ends sensitive to deliberation). And we are responsible for them for the same reason.54 But presumably, this explanation of what makes us responsible for elicited acts of will will apply to other appetitive responses to free judgments. 55 Someone is responsible for all of her appetitive responses to free judgments. Thus, it is a sufficient condition for responsibility for our appetitive states that they be caused per se by free judgments, judgments that are the result of or could have been modified by deliberation.

This should make it obvious why Aquinas thinks showing that passions are reason-dependent is sufficient for showing that we are responsible for them. A passion that is reason-dependent is caused per se by a free judgment (a judgment that is the product of reason's capacity for deliberation, or could have been modified as a result of such deliberation). Unlike the will, which responds to free judgments directly, the sensory appetite responds indirectly, through the mediation of the particular reason and the imagination. But I don't see why this mediation would make a difference where the freedom of our volitions and passions is concerned. Therefore, we are responsible for reason-dependent passions because they are caused per se by evaluations sensitive to deliberation. 56

53. It is only in relatively rare cases of emergency actions that Aquinas allows himself to use the Aristotelian explanation of indirect responsibility: "Custom produces necessity not absolutely, but in unexpected situations-for no matter how accustomed, through deliberation, one can act against custom" (QDM 6 ad 24). When custom produces necessity in emergency situations, then the agent will be held responsible because she could have altered her dispositions in the past. But in all other cases, the agent is directly responsible because she could alter her dispositions and her values through deliberation.

54. Aquinas argues that cases of compulsion, where the agent's judgment was not free but compelled to evaluate an object in a particular way by her passions, do not involve acts of will. If the agent acted under internal compulsion, he claims, she acted in the way non-human animals do, directly on the basis of passion, without passing through free judgment and will. It follows from this that an act is either the product of free judgment and voluntary elicited acts of will or not a product of free judgment or elicited acts of will at all. Therefore, there are no involuntary acts of the will. See esp. ST Iallae 10.3c.

55. For a similar, very sophisticated account of responsibility in Aristotle, see T. Irwin, "Reason and Responsibility in Aristotle, " in Essays on Aristotle's Ethics, A. Rorty, ed. (Berkeley: U niversity of California Press, 1980), pp. 117-55.

56. I said much earlier in this essay that showing that we are responsible for what Aquinas calls passions will, by extension, show that we are responsible for what we call emotions. If emotions are a category that includes both attitudes and cognitions (probably both intellective and sensory attitudes to objects of both cognitions), then Aquinas's account of freedom and responsibility will be just the 


\section{EXTRINSIC CONTROL}

This account of our responsibility for passions focuses on the rationality of some passions and on their dependence on the final reasoned judgment of the person. But of course, there is another aspect of the passions that has been part of philosophical common sense at least since (post-Socrates) Plato. The passions are sometimes irrational, opposed, and insensitive to reasoned judgment, influencing the person against her reasoned principles. Aquinas recognizes this as a problem for his intellectualist account of the passionsand our responsibility for them. In almost all the questions where he defends the view I've been laying out, he raises the following objection. 57

That which obeys something else does not resist it. But passions do resist reason, as the Apostle says in the letter to the Romans 7: "I see another law in my members, warring against the law of my mind." Therefore, the passions do not obey reason. 58

In reply, Aquinas grants the observation that some passions do not obey reason, but denies the objector's conclusion: that if some passions are not dependent on reason's deliberation, none of them are. All St. Paul's observation shows is that not all passions are reason-dependent, and thus not all passions are voluntary in the way l've been describing. But as we've seen, Aquinas agrees: not all passions are caused by a judgment of the particular reason; some are caused by imagination and sense.

Given everything I've already said, I think the best way to explain the

right one to show that we are responsible for them. Aquinas's account argues that we are responsible for appetitive acts (pro and con attitudes) because of the freed om of intellective evaluative cognition (free judgment). Therefore, his argument shows not only that we are responsible for appetitive responses, but also for their cognitive causes. $\mathrm{H}$ is name for the freedom associated with responsibility is 'liberum artbitrium,'- free judgment, not 'libera voluntas,' - free will (see, e.g., ST Ia 83). So, if he has succeeded in showing that we are responsible for volitions and reason-dependent passions because of their relationship to deliberation and free judgment, then surely his account will also succeed in showing that we are responsible for complexes of cognition and attitude called emotions. In what follows, therefore, I assume that whatever Aquinas has shown about our responsibility for our passions holds also for our responsibility for our emotions. Therefore, I will sometimes allow myself to slip and talk about our responsibility for emotions rather than using passion consistently as I did in the first part of the paper.

57. ST Ia 81.3 obj.2, ST Iallae 17.7 obj.1, QDV 25.4 obj.1,2.

58. ST Ia 81.3 obj.2: "Quod obedit alicui, non repugnat ei. Sed irascibilis et concupiscibilis repugnant rationi, secundum illud Apostoli, ad Rom. vii: “Video aliam legem in membris meis, repugnantem legi mentis meae' Ergo irascibilis et concupiscibilis non obediunt rationi." 
distinction between passions that are reason-dependent and ones that are not is the following. The sensor y appetite is naturally moved by two sorts of things: the cognition of objects as having naturally attractive properties (those which are sensory goods, such as pleasure, survival, self-assertion), and the judgment of particular reason that some object ought to be shunned or pursued. Passions that are the result of the sensory appetite's natural craving for pleasure and self-assertion are not reason-dependent, while those that are the result of the sensory appetite's natural sensitivity to judgments of particular reason (which itself applies the universal reason's all-things-considered judgment to particulars) are reason-dependent. Reason-dependent passions are ones which I can explain in terms of the connection between their object and goodness in general. My explanation for reason-independent passions will stop at one of the sensory goods that naturally move my sensor y appetite, but won't be able to appeal to goodness in general, or overall. I desire to gossip with my friends because of my natural curiosity and craving for their admiration of my intimate knowledge of our acquaintances, not because I believe it's good. But I despise and desire to stop my habit of gossiping because I have judged, all-things-considered, that it would be best to stop.

Of course, I may have judged all-things-considered that the pleasure I derive from gossiping is more valuable than showing respect for other people. Then my desire to gossip will be reason-dependent despite the fact that I desire it because it's a sensory good. That's because in this case, the sensory appetite will have influenced the judgment of my reason so that I judge that the sensory good is what ought to be pursued.59

The fact that passions can be responses to the mere cognition of an object as having a certain property, as well as to the judgment of particular reason explains how there can be passions in opposition to the person's reasoned judgments (to dispositional or occurrent reasoned judgments). These passions are not responses to free judgments. Therefore, if we are responsible for them, it cannot be because they are caused by judgments that are the result of or could have been modified by deliberation. Aquinas offers two different kinds of explanation of our responsibility for reasonindependent passions. The first relies on an account of indirect counterfactual control (that is, control we have over our habits and tendencies over

59. On the influence of the sensory appetite on reason and the will, see ST Iallae $9.2,10.3,77.1,2,3,6,7,8$. This interpretation of the relation between the sensory appetite and reason helps to explain what Aquinas means when he says that some vices are in the sensory appetite. All vices involve reason's having formed bad values. So there cannot be a vice that is exclusively a disposition to have bad passions. However, all the vices Aquinas locates in the sensory appetite are concerned with sensory goods (broadly speaking) - lust, gluttony, cowardice, curiosity, pride, avarice, pusillanimity, and so on. So vices of the sensory appetite seem to be conditions in which an agent is disposed to prefer sensory goods to other goods when she forms reasoned judgments. 
time) to explain how we can be responsible for reason-independent passions that arise spontaneously. The second relies on an account of direct counterfactual control (that is, control we have over our emotions as soon as we desire to exercise it, typically through the mediation of the imagination) to explain how we can be responsible for reason-independent passions that are allowed to persist.

\section{(1) Responsibility for Spontaneous Reason-independent Passions}

Aquinas argues that reason-independent passions that arise spontaneously can be sinful:

We don't say that there's sin in sen suality because of the implied consent of reason, since when a movement of sensuality [that is, a passion] precedes the judgment of reason, there is no consent, whether implied or expressed. But because sensuality can be subjected to reason, it has the defining characteristic of sin even if its act precedes reason. 60

If a passion that precedes the command of reason can be sinful, then it's possible for us to be responsible for it. (Only acts for which we're responsible can be the subject of moral evaluation, and 'sinful' is a term of moral evaluation.) But as it is reason-independent, our responsibility for it cannot be explained by the fact that it is caused by deliberation. Perhaps we can try a very simple counterfactual account: we are responsible for these spontaneous passions because though they are not caused by deliberation, they could have been affected by deliberation. $\mathrm{H}$ ad the person deliberated, she might have affected her emotional response through a judgment of particular reason. But this account fails since the passion is a spontaneous response to a spontaneous evaluation supplied by the imagination. Thus, though the person may perhaps be able to do something about her passion once she's noticed it, she could not have altered it before it occurred. How then can Aquinas maintain that we can be responsible for such passions?

A movement of the sensory appetite is sometimes aroused suddenly, in response to imagination or sensory cognition. And in that case, such a movement occurs without the command of reason, although it could have been prevented by reason if it had been foreseen. 61

60. QDV 25.5 ad. 5: "N on dicitur esse peccatum in sensualitate propter interpretativum consensum rationis: quando enim motus sensualitatis praevenit iudicium rationis, non est consensus nec interpretatus nec expressus; sed ex hoc ipso quod sensualitas est subiicibilis rationi, actus eius quamvis rationem praeveniat, habet rationem peccandi."

61. ST Iallae 17.7c: "Contingit autem etiam quandoque quod motus appetitus sensitivi subito concitatur ad apprehensionem imaginationis vel sensus; et tunc ille motus est praeter imperium rationis, quamvis potuisset impediri a ratione si praevidisset." 
If it's the case that a spontaneous passion could have been prevented if it had been foreseen, and it was foreseen, then it is what Aquinas calls indirectly voluntary because "something can be called voluntary directly or indirectly. That which the will seeks is directly voluntary; that which the will can prevent but does not is indirectly voluntary." 62 We would say that someone is responsible because she had counterfactual control over the passion-had she exercised her control, the passion would not have occurred. Thus, a person will be responsible for passions which she could have prevented but did not prevent (when she has counterfactual control). And a person could have prevented a passion if she could have foreseen it. So people will be responsible for those reason-independent passions that could have been foreseen.

How might the passion have been foreseen? I can see two different ways in which a passion can be foreseen. (1) O ne may be able to foresee, at least broadly, what sorts of objects one is likely to encounter; and (2) one may be able to foresee how one will react to different sorts of objects if and when one encounters them. A person who has both kinds of foresight ([1] and [2]) will have a very strong degree of foresight, which will yield a very strong degree of control. If I know that I tend to feel excessive anger towards sexist men, and I suspect that my friend's new husband is sexist, I can try to avoid undergoing the passion by trying to avoid meeting him, by talking to him as little as possible, and by being on my guard for the passion while I do talk to him. I think the claim that having this strong foresight (based on self-knowledge and knowledge-and foreknowledgeof the world) makes one responsible for one's passions is very plausible. If politeness and friendship demand that I spend some time talking to my friend's husband, I may very well think to myself something like: 'I'II undoubtedly get excessively angry, and it will be unpleasant, but it will be better than refusing to talk to him'. It seems pretty clear in a case of such clear foresight that I am responsible for the passions that develop, since I choose a course of action that includes them from among a set of alternative options. The intuitive character of the judgment that we're responsible for passions we can foresee with this degree of foresight seems based on the strong degree of control it yields. But we don't often have this amount of control, since for the most part, we don't know what we're going to encounter.

On the other hand, if I know that I habitually feel excessive anger towards men who seem contemptuous of women, I can exercise a different sort of control as a result of a more general and weaker sort of foresight (just foresight [2] without [1]). I can try to rid myself of the habit of experiencing such excessive passions. Emotional habits, whether they are rational or irrational, arise from habitual associations of certain types of

62. ST Iallae 77.7c: "Aliquid dicitur voluntarium directe, vel indirecte: directe quidem, id in quod voluntas fertur; indirecte autem, illud quod voluntas potuit prohibere, sed non prohibet." 
objects with certain properties or evaluations. I may recognize, as a result of correct reasoning, that sexist men do not deserve to be resented with such intensity, but nonetheless know that I will experience the irrational passion if faced with such men. This sort of weak or conditional foresight should enable me to try to alter my emotional habit. Since I judge correctly that my habit is founded on an irrational association, I can try to correct the association and create a new one, through reason's power over imagination, through particularizing my reasoned judgments, et cetera. By systematically recasting the situation every time I evaluate it irrationally, I might be able to acquire a new habit of evaluating the situation properly (of associating the right sort of evaluation with this sort of situation).

Presumably, this is what Aquinas means when he says that "because sensuality can be subjected to reason, it has the defining characteristic of sin even if its act precedes reason." 63 Because individual occurrences of passions can be affected by our deliberated free judgments, and because habits are formed by the repetition of similar acts, a bad emotional habit may be eradicated by consistently correcting one's passions when they occur. We can then, with some effort, form good emotional habits in ourselves and rid ourselves of those we judge to be bad. Thus, my account of the claim that the person could have foreseen the emotion and done something about it is as follows: either (1) the person could have done something about her habit as a result of weak foresight ( since she has some control over particular passions, and therefore indirect control over emotional habits that arise from repeated particular passions); or (2) given the fact that she had the habit, and could not in the short term do anything to rid herself of it, if she had strong foresight about what she would encounter, she could have done something not to get into a situation where she would undergo the passion.

Either of these abilities to foresee and avoid emotional reactions yields the more general claim that the person could have (indirectly) avoided the passion. But this fits Aquinas's account of what he calls an indirectly voluntary state (though I'm calling it voluntary through counterfactual control). Therefore, the consequence of weak foresight is that we are (at least partly) responsible for any of our passions that arise because of our habitual disposition to feel such passions (they are indirectly voluntary because we have counterfactual control over them). The consequence of strong foresight is that in the rare cases where we can foresee our future circumstances, we are (somewhat more fully) responsible for the passions that arise as a result of the combination of these circumstances with our habitual dispositions to undergo passions in such circumstances.

Of course most of the passions we undergo could not have been foreseen in the strong sense because we had no idea what situation we were

63. Of course, this is true only when the movement of sensuality is bad in some way. When it is not irrational, the movement of sensuality that precedes reason is not a sin (though whether it can be positively good is a more difficult question). 
about to encounter, or how we would react to it, given all the circumstances in which it occurred. So we are not responsible in the stronger sense for most of our reason-independent passions. Moreover, although probably many of our emotional reactions are due to habitual acquired dispositions, which we could correct if we tried, clearly not all spontaneous reason-independent passions are. Passions need not be the result of habits; they may be the product of a momentary mood or disposition, and in this case they cannot be foreseen even in the weak sense.

Moreover, foresight, whether weak or strong, doesn't automatically yield counterfactual control. It does so only in cases where reason could have avoided the passion if it had been foreseen. But Aquinas himself seems to admit that there are cases where, though the emotion admits of weak foresight ( the person knows that she tends to react in certain ways in certain situations), there is nothing the person can do to rid herself of the disposition. Some passions or emotional tendencies are the consequence of irremediably fallen human nature. Although a very attentive and self-knowing person knows that she falls prey to such passions, she also can't help it. In fact, Aquinas recognizes that even the ideally moral person, one who is completely virtuous in both secular and religious senses will, upon coming across unexpected situations, undergo irrational emotions. 64 In such cases where foresight does not guarantee control, the person is not responsible for her reason-independent spontaneous passion.

As we'll see shortly, however, although the person who undergoes such emotions is not responsible for the first stirrings, the 'first movements' as Aquinas aptly calls them, she may still be responsible for her attitude to them, and for their continuing and developing. She is not responsible for the first stirrings of adulterous lust, or triumphant pride, or jealousy, and envy. But she may very well be responsible for all of those if they last more than a moment, or if she does nothing to fight against them.

\section{(2) Responsibility for Prolonged Reason-independent Emotions}

Aquinas actually has little to say about indirectly voluntar y emotions. He has a lot more to say about how emotions can be voluntary once the emotion

64. On first movements see, e.g., DM 7.6 ad 8, 7.8; ST Iallae 89.5; SR n. 563. For a fuller and more sophisticated discussion of the moral implications of these emotions, see N. Kretzmann, "Warring against the Law of my Mind: Aquinas on Romans 7," in Philosophy and the Christian Faith, T. Morris, ed. (South Bend, In.: U niversity of N otre Dame Press, 1988), pp. 172-95. Kretzmann's study of Aquinas's commentary on Romans shows that Aquinas saw Paul as a man of grace, ideally moral in both religious and secular senses, afflicted by these first movements which, though he could foresee them in a general way, he could not entirely eradicate in himself, hence the lament about doing the evil which he did not will (having these emotions). 
has occurred, because the person could have done something about it if she had chosen to do so.

We've already seen that the sensory appetite obeys reason because reason can affect the content of the imagination, which provides the sensory appetite with its object. When someone undergoes a spontaneous reason-independent passion, she can deliberate about the evaluation of the object that causes it. If she concludes that the evaluation is correct, she will endorse the passion and thus make it reason-dependent. If she concludes that the evaluation in the passion is false, or that the object of the passion, though good in certain respects, is not good overall, she can recast the object or the situation in her imagination in such a way as to alter her passion, to calm or dispel the original one and to elicit a new, appropriate one. If she's successful, then the resulting passion will be reason-dependent. If, on the other hand, she fails to deliberate, or fails to try to modify her own passion when she has judged that its evaluation is false, then we can say that it was in her power to deliberate and to alter her emotional state. Her failure to deliberate or to apply the conclusion of her deliberation to her imagination, then, constitute voluntary omissions. Now, the passions "are called voluntary either because they are commanded by the will, or because the will does not forbid them." 65 Therefore, since the person could have directly altered her emotional state and did not, the passion is again voluntary because of the person's counterfactual control over it.

In order for this account of direct voluntariness to hold, Aquinas has to show that we do indeed have the necessary direct sort of control over our passions. At his most optimistic, Aquinas seems to think that we can not only dispel an unwanted emotion in ourselves, but also elicit one that we want: "by applying some universal considerations, he can calm his anger or fear, or anything of the sort; or he can also arouse them." 66 Before I consider the first claim, which is much more plausible, I will say a few words about why Aquinas himself cannot be committed to the second. A passion requires three things: a particular evaluative cognition, an appetitive movement, and a bodily change. It may be true that we can typically elicit particular evaluative construals in ourselves at will (although I have my doubts about that, as I will point out). But unless the appetitive and bodily components of the passion follow necessarily from their cognitive cause, more is needed to elicit a passion. And Aquinas does think that more is needed.

$\mathrm{H}$ e seems to think that when the body is in good health and a normal condition, and when the appetite is at rest, then appetite (the pro or con attitude to the object) and bodily change just follow necessarily from cognition. But he also thinks that when there is anything unusual with the body

65. ST Iallae 24.1: "[Passiones] dicuntur autem volunariae vel ex eo quod a voluntate imperantur, vel ex eo quod a voluntate non prohibentur."

66. ST la 81.3c. 
(because it is ill, congenitally malformed, or just momentarily excited), or when the person is already experiencing a passion of the sensory appetite, then the intensity of the appetite and the occurrence or nature of the bodily change will be affected by factors other than cognition. So, from the fact that it is always possible to elicit particular evaluative construals in the imagination, it does not follow that it is always possible to elicit passions, since passions are constituted by more than just cognition. 67

I will discard the possibility that we al ways have control over eliciting our passions. This means that we can't al ways be held responsible for not undergoing a passion when we should be feeling one. H owever, what I have said does nothing to disprove the possibility that we are responsible for all prolonged reason-independent passions we do undergo, because we could always have calmed or dispelled them in oursel ves. To show that this is the case, Aquinas must show that it is possible, with a reasonable amount of effort, for someone who's undergoing a passion to reconsider the situation, form an independent reasoned judgment about it, and alter her construal of it, thereby getting rid of the unwanted passion (even if the bodily changes which are not under our direct control can persist, they don't on their own constitute a passion). It seems just fal se, however, that in ever y case when we are undergoing a passion, we can just stop in our tracks, review the evaluation to which we are reacting, and calmly deliberate about it. When I'm at the height of my anger against my friend's sexist husband, it's not clear it would be possible for me to review the data and come to a more rational judgment, in the way it might have been possible before l lost my temper.

In fact, although Aquinas does think that if we can succeed in getting our imagination under our control, we can have this amount of control over our passions, he also realizes that we don't all or al ways have this amount of control.

\section{(3) Problems for the Counterfactual Account: Forms of Lack of Control}

Aquinas admits that some people chronically lack the relevant kind of control over their imagination, because their faculty of imagination is deficient as a result of some physiological problem (just as someone born paralyzed lacks control over the movements of her limbs).

67. See ST Iall Iae 17.7c: "It's important for us to know that the sensory appetite differs from the intellective appetite, which is called the will, because the sensory appetite is the power of a bodilyorgan, whereasthe will isnot. But ever yact of a power that uses a bodily organ depends not only on a power of the soul, but also on a disposition of the bodilyorgan. For instance, sight depends on the power of sight and the condition of the eye, by which it is helped or hindered. That's why the act of the sensory appetite depends not only on the appetitive power, but also on the condition of the body. That which comes from the power of the soul follows apprehension.... But a condition and disposition of the bodyisnot subject to the command of reason." 
The apprehension of the imagination issubject to the ordering of reason in proportion (secundum modum) to the strength or weakness of the imaginative power. For that a human being cannot imagine what reason considers occurs either because what reason considers connot be imaginged (e.g., incorporeal things), or because of a weakness in the power of the imagination which comes from some defect in the organ. 68

For those who are born 'imaginatively challenged', therefore, there is no (or diminished) control of the imagination in the wayl've described, and so no (or diminished) responsibility for prolonged reason-independent passions. 69 H owever, as in the case of physical paralysis, the fact that such people exist does not show that ordinary people don't have the right sort of control over their imaginations.

Aquinas sometimes offers a different explanation for deficiencies in the imaginative power or the memory. He follows Aristotle in the claim that through practice we can make our memory and imagination quicker and more reliable.70 In such a case, the person's lack of control over her own reason-independent passions will be traced back to a voluntary omission, and she will be indirectly responsible for her lack of control.

But lack of rational control over imagination need not be chronic or habitual, it may also be episodic or occur not as the result of settled dispositions or conditions. Aquinas argues that someone who is undergoing a passion has greatly reduced control over her own imagination. This comes about in two general ways. The first is that when someone is undergoing a passion, her ability to deliberate is reduced. Her ability to form all-thingsconsidered judgments, to recall, or to actualize dispositional evaluative judgments is reduced. The second is that when someone is undergoing a passion, even if she succeeds in deliberating or judging properly, her reason's control over her passions is drastically reduced.

From the fact that some passions completely take away the ability to

68. ST Iallae 17.7 ad 3: "Apprehensio autem imaginationis subiacet ordinationi rationis, secundum modum virtutis vel debilitatis imaginativae potentiae. Quod enim homo non possit imaginari quae ratio considerat, contingit vel ex hoc quod non sunt imaginabilia, sicut incorporalia; vel propter debilitatem virtutis imaginativae, quae est ex aliqua indispositione organi."

69. The 'imaginatively challenged' person won't be the sort that we ordinarily call 'unimaginative'. She will be someone who has particular trouble moving from abstract thought to particular, detailed, examples represented in phantasia through sensory properties. The scientist J. Craig Venter recently described himself this way: "'When I close my eyes,' he begins, 'I see nothing. I can't picture my wife's face; I can't picture my boat. ... All my thinking is totally conceptual'" ( Lisa Belkin, "Splice Einstein and Sammy Glick: Add a Little Magellan," The N ew York Times M agazine, August 23, 1998). He seems to me to be an example of someone Aquinas would have described as imaginatively challenged. Great philosophers such as Kant, and perhaps even Aquinas himself might also fit the description, if we take their philosophical writing and its paucity of examples as evidence of their mental disposition.

70. See ST I al Iae 50.3 ad 3, and ST I al Iae 56.5: The reference to Aristotle is De $\mathrm{M}$ emoria et reminiscentia ii, and De M emoria ii. 
reason, Aquinas infers that undergoing a passion greatly affects our ability to reason. If, as he argues, it is sometimes the case that very intense passions make it impossible for some people to reason at all, then lessintense passions must affect our ability to reason, even if they do not take it away entirely. ${ }^{71} \mathrm{He}$ gives several explanationsfor this, which I think can be summed up by saying that we have a certain amount of attention or capacity for consciousness, and when a lot of attention is demanded for one object, there is less to give to others. Because passions involve not only a psychological state, but also a physiological one, they tend to demand and obtain more immediate attention than other psychological activities (and the more intense they are, the more attention they command). As a consequence of this hijacking of the person's attention by the reason-independent passion, not much attention or psychic energy is left to the person for reconsidering the evaluation or examining the data rationally to see whether the passion is justified. So because she cannot concentrate, and therefore has great difficulty examining the data independently of the passion, it's difficult for her to formulate a reasoned evaluative judgment, or even to make occurrent a judgment that she has dispositionally. If undergoing a passion makes it difficult for someone to reason and achieve an evaluative judgment independently of the passion, then it also makes it difficult for her to affect her imagination, and it explains why her control over her passions is reduced.

A person's abilityto deliberate when she is al ready undergoing a passion is weakened by the passion's distracting all her attention away. But it is also weakened by the power which the passion has over her reason. It is al ways the case that an imaginative sensory evaluation of an object is part of the data considered in the formation of a final reasoned judgment of a situation.72 When I'm trying to decide whether to gossip or not, I take into account as part of my data, the fact that gossiping will be very pleasurable. So I al ways consider my own sensory evaluation as a potential reason to form a reasoned judgment in accordance with that evaluation. If my capacity for deliberation is greatly reduced, so that I find it difficult to consider any other aspect of the object, or to detach my attention from the fact that gossiping will be pleasurable, then it will be easy to accept as the conclusion of my deliberation the evaluation presented to me by my imagination. Instead of forming a particular judgment and a passion on the basis of a final judgment, I'll form a final reasoned judgment on the basis of my passion. ${ }^{73}$ Aquinas's view, of course, is

71. See ST Iallae 10.3c, 77.1c, 77.7c.

72. See DM $6 c$, where Aquinas claims that even the will has a natural inclination to sensory goods such as survival.

73. See ST Ial Iae 77.2 ad 4. Aquinas follows Aristotle in his analysis of weakness of the will: the akratic knows the right universal evaluation, but her passion prevents her from reasoning from that universal to a particular correct conclusion. Instead, she calls to mind a different universal proposition "suggested by the inclination of the passion" and reasons herself to an incorrect conclusion from this new universal. For general accounts of the power of passions over reason and will, see ST Iallae 9.2, 10.3, 77.1, 77.6, 77.7, QDV 26.6. 
that reason isfor the most part free to resist thisinfluence, and that al though the capacity for deliberation is reduced when we're undergoing a reasonindependent passion, so that deliberation requires greater effort, it is nonetheless not destroyed. 74

On the other hand, even if the person undergoing a passion reaches a final judgment as a result of deliberation, she may not be able to affect her passion.

The judgment and apprehension of reason are disturbed by a strong and disordered apprehension of the imagination and judgment of the estimative power, as exemplified by those who are out of their minds. But it's clear that the apprehension of the imagination and the judgment of the estimative part follow a passion of the sensory appetite, in the same way that the judgment of taste follows the disposition of the tongue. That's why we see that men who are in a state of passion do not easily turn their imagination from the things they like [afficiuntur]. That's why it follows that the judgment of reason (and consequently a movement of the will whose function it is to follow the judgment of reason) often follows a passion of the sensory appetite. ${ }^{75}$

When the sensory appetite is not yet undergoing a passion, then it is equally responsive to things it recognizes as sensory goods and to the judgments of the particular reason. But once it is already undergoing a reason-independent passion, then it is no longer so responsive. This is because the only access reason has to the sensory appetite is through the particular reason. But, Aquinas tells us here, when we are al ready undergoing a passion, the judgment of the particular reason tends to follow the passion (in the way a judgment of taste (I love licorice) follows the feelings produced by the object on the tongue (a peculiar kind of sweet and pungent sensation)). So, when I'm in the middle of my irrational anger against my friend's sexist husband, my particular reason will conclude that rude and aggressive things ought to be said to him, because he appears punishable to me in my anger. But if my particular reason is taken over in this way by my passion, it will not be able to present the judgments of universal reason to the sensory appetite (for example, that, all-things-

74. Aquinas does allow for cases in which emotion causes insanity, that is, where the very capacity for reasoning is destroyed by the power of the emotion. But these are clearly very rare. See, e.g., ST Ial Iae 6.7, 10.3, 77.7.

75. ST Iallae 77.1c: "Impeditur enim iudicium et apprehensio rationis propter vehementem et inordinatam apprehensionem imaginationis, et iudicium virtutis aestimativae: ut patet in amentibus. Manifestum est autem quod passionem appetitus sensitivi sequitur imaginationis apprehensio, et iudicium aestimativae: sicut etiam dispositionem linguae sequitur iudicium gustus. Unde videmus quod homines in aliqua passione existentes, non facile imaginationem avertunt ab his circa quae afficiuntur. Unde per consequens iudicium rationis plerumque sequitur passionem appetitus sensitivi; et per consequens motus voluntatis, qui natus est sequi iudicium rationis." 
considered, even though this man is odious, I ought to stay polite for the sake of his and my friend's feelings). So the sensory appetite, when it is undergoing a passion, is much less sensitive to the all-things-considered judgments of reason.

\section{(4) Reason's Attitude to the Passions}

But then what can we say about our responsibility for prolonged reasonindependent passions if the degree of control we have over them is really so slight? In the face of the famous lament from St. Paul, "I do not do the good that I want, but the evil which I hate, that I do," interpreted as a claim about the lack of control we have over our own desires, Aquinas uses one last explanation of what is voluntary in cases where the passion is not sensitive to reasoned judgment.

The will cannot prevent the movement of concupiscence from arising, about which the apostle says, 'The evil which I hate, that I do-i.e., 'I lust'. Nonetheless, the will can will against concupiscence, or refuse to consent to concupiscence. 76

and

When there is an illicit movement in sensuality, reason can be related to it in three ways. (1) In one way, so that reason resists it; and in that case there is no sin, but rather the meriting of a crown. (2) In a second way, so that reason commands it, as when one elicits a movement of illicit desire on purpose. And then, if the illicit movement is in the genus of mortal sin, [reason's eliciting the illicit movement] will be a mortal sin. (3) And, in a third way, so that reason neither forbids nor commands, but consents. And then [ reason's consent] is a venial sin. ${ }^{77}$

These two passages show that the main source of responsibility for reason-independent passions is the person's attitude toward her passions, and not the passions themselves. She can resist them (in which case Aquinas must think she is entirely blameless, since he claims she merits a crown), or endorse them (in which case they become reason-dependent

76. ST Iallae 10.3 ad 1: "Etsi voluntas non possit facere quin motus concupiscentiae insurgat, de quo apostolus dicit: quod odi malum, illud facio, id est, concupisco, tamen potest voluntas non velle concupiscere, aut concupiscentia non consentire."

77. QDM 7.6 ad 6: "Quando motus illicitus est in sensualitate, tripliciter se potest ad ipsum habere ratio. Uno modo sicut resistens: et tunc nullum est peccatum, sed est meritum coronae. Aliquando autem se habet ut imperans, puta cum ex proposito motum concupiscentiae illicitae excitat: et tunc si sit illicitum in genere peccati mortalis, erit peccatum mortale. Aliquando autem se habet ut neque prohibens neque imperans, sed consentiens; et tunc est peccatum veniale." 
and entirely voluntary), or consent to them. ${ }^{78}$ The distinction between consent and endorsement is clarified by Aquinas's assessment of the person's guilt. Endorsement must mean that the person, influenced by the passion, forms a deliberated judgment concluding that the evaluation of the situation in the passion is correct and to be adopted. That is why she herself becomes guilty of whatever moral badness the passion exhibited. Consent must mean that though the person does not attempt to resist the evaluation in the passion, she also does not endorse it. Her reason remains inactive, and the passion continues on its course without any judgment of reason having been formed. 79 Reason has consented because it has failed to resist, but it has not endorsed because it has not been influenced into forming a judgment.

But the question at hand is how much control reason has over passions. The person's reason has complete control over her reasoned attitudes to her emotions, and so she is entirely responsible for her own attitude. But how completely does Aquinas think that reason's attitudes control the passions? The answer lies in understanding whether he thinks that a passion can persist in the face of utterly sincere resistance from reason. I think the following passage clarifies that issue.

Since in human beings there are two natures-namely intellective and sensory - sometimes indeed, a human being is uniformly [ disposed] in one way throughout his entire soul, either because the sensory part is completely subject to reason, as happens in the virtuous, or on the contrary, because reason is completely swallowed up by passion, as

78. Aquinas uses 'corona' or crown as synonymous with 'au reola' or halo to refer to the "reward added to the essential bliss of heaven for spiritual victories achieved on earth" R. J. Deferrari, Latin-English Dictionary of Thomas Aquinas (Boston, Mass.: St. Paul ed., 1986), p. 235 Clearly, if one can receive a reward that is additional to eternal happiness, one must be ideally moral, and so it cannot be imputed to one as a moral fault that one has bad emotions that do not cease when one fights against them with all one's strength.

79. Although 'consent' sounds more active than what I describe here, I think there are compelling reasons for this interpretation. In ST Iallae 74.6, Aquinas describes two ways in which reason can be sinful because of its failure to direct the passions: when it commands bad passions and when it fails to check bad passions. In 74.7 ad 2, Aquinas argues that when reason fails to direct actions properly, it is said to consent, even when the agent is not conscious of the misdirection. Because Aquinas allows that sometimes consent means merely failure to direct properly, and because the distinction he draws at 74.6 between reason's commanding bad passions and reason's failing to check them seems very similar to the distinction at hand, I am interpreting 'consent' here to mean reason's failing to do anything about bad passions. This is al so explains the different degrees of sinfulness attached to each case: reason's commanding a bad passion is a mortal sin, whereas reason's failing to check one is only a venial sin (even if the passions is very bad). On the other hand, if consent were meant to imply much more than failure to check, it would be difficult to understand why Aquinas asserts that in the case of consent, we only have venial sin. 
happens in the insane. But other times, although reason is clouded by passion, it does retain some freedom. And because of this, one can either completely push away the passion, or at least restrain oneself from following the passion. For in such a disposition, because a human being is disposed in different ways by the different parts of his soul, something appears to him in one way according to reason, and in a different way according to passion. 80

In this passage, Aquinas seems clearly to recognize the possibility of someone's continuing to undergo a passion despite reason's resistance. That means that while the passion continues, it is not the case that the person could have prevented it if she'd tried, since she is trying-and failing - to prevent it. The account of responsibility in terms of counterfactual control does not work for such passions. In fact, Aquinas seems to think they are not voluntary at all, since he claims that someone who undergoes an illicit emotion but resists it is not sinning at all but rather meriting a crown. She merits a crown because all her voluntary activities are good, and because the only bad thing in her, her passion, is entirely involuntary. So all that is voluntary in such cases, all that the person is responsible for, is her attitude toward her passions. 81

\section{CONCLUSION}

The great strength of Aquinas's complicated view of our responsibility for our emotions seems to me to rest in the fact that it distinguishes between cases in which responsibility for emotions depends on someone's control over these emotions and cases in which it does not. We are responsible for reason-independent emotions only when we could have avoided them (in

80. ST Iallae 10.3 ad 2: "Cum in homine duae sint naturae, intellectualis scilicet et sensitiva, quandoque quidem est homo aliqualis uniformiter secundum totam animam, quia scilicet vel pars sensitiva totaliter subiicitur rationi, sicut contingit in virtuosis; vel e converso ratio totaliter absorbetur a passione, sicut accidit in amentibus. Sed aliquando, etsi ratio obnubiletur a passione, remanet tamen aliquid rationis liberum; et secundum hoc potest aliquis vel totaliter passionem repellere, vel saltem se tenere ne passionem sequatur. In tali enim dispositione, quia homo secundum diversas partes animae diversimode disponitur, aliud ei videtur secundum rationem, et aliud secundum passionem."

81. Judith Barad mistakenly identifies this view as Aquinas's only considered view of our moral responsibility for emotions. See Barad, "Aquinas on the Role of Emotion in Moral Judgement and Activity," The Thomist 55 (1970): 397-413. It should be clear at this point that Aquinas thinks our emotions themselves can be voluntary in many ways, and that it is only in special cases where the emotions are entirely insensitive to reasoned judgments that he weakens his view to the claim that we are responsible only for our own reactions to emotions, and not for the emotions themselves. 
one way or another), when they are either directly or indirectly in the control of our reason and will. On the other hand, our responsibility for reason-dependent emotions just follows from their nature (as caused by our reasoned evaluative beliefs and judgments, as long as those are free). O ur responsibility for our reason-dependent emotions should not be thought of in terms of control, because they are just extensions from the faculties in us that do the controlling, not as their objects but as their consequences.

The strength of this non-reducible two-fold approach to our responsibility for emotions (in terms of control or in terms of reason-dependence) seems to me clearly demonstrated in the following two examples.

Suppose Nicolas has been raised by a tyrannical and overbearing mother and as a result, tends to be servile and resentful towards women when they are in a position of authority over him. He is now in a new job where his two closest superiors are women, and he constantly finds himself craving their approval while resenting all their demands and maliciously gossiping about them. As a result of counseling, Nicolas acknowledges to himself that these emotions are irrational, that their sources are his past and his relationship with his mother rather than any properties of his two bosses themselves. So his reasoned judgment is that these women deserve neither his ser vile attentions nor his malice. $\mathrm{H}$ is emotions, then, are reason-independent, so they are appropriately examined in terms of the control he has over them. I don't think our intuitions are very clear about whether or not Nicolas has control over these emotions. Given the sketchiness of the example, we will tend to be ambivalent between two positions. (1) Nicolas has no control over his irrational emotions because though he has formed a reasoned judgment opposed to them, and is fighting against them, he nonetheless undergoes them. Therefore, Nicolas is not responsible for his irrational emotions. (2) Although Nicolas claims, or even himself believes, that he is fighting against his irrational emotions, he has covertly assented to them (or, worse, he covertly endorses them). The fact that his emotions persist is a sign that he is not fighting against them hard enough. Therefore, Nicolas is at least partly responsible for his emotions.

If we build into the example the fact that Nicolas is doing all he can to rid himself of emotions he detests, then we will tend to agree with Aquinas that since he is not in control of his emotions, Nicolas is not responsible for them. If, on the other hand, we build into the example the fact that Nicolas is deceiving others or himself, we will tend to agree that he is responsible, at least for not working harder or ridding himself of them. It is, of course, an empirical question in each case whether someone does or does not have control over his reason-independent emotions. Aquinas's position, as I have analyzed it, is merely that, on the assumption that Nicolas has control (in the ways I've described) but fails to exert it, he is responsible, while on the assumption that Nicolas lacks control he is not responsible. It seems to me to be a strength of Aquinas's account that he allows for both possibilities, 
so that he leaves it to be determined in each case whether the person did or did not have control.

Although Aquinas leaves the determination of whether a person is responsible for his reason-independent emotions in the hands of the person who has all the empirical data, he does give us a different, more abstract guide for determining moral accountability. Even if we are unable to determine the degree of control we or others have over our reason-independent emotions, it should be easier to determine what our attitude to these emotions is. Examining someone's attitude, as expressed in his actions, his reasoning, his whole-heartedness in ridding himself of bad tendencies, will reveal something about his moral accountability, if not for the emotions themselves, then at least for his attitude to his emotions. If Nicolas is genuinely fighting against his irrational emotions (if they are in no way accepted or endorsed by his reason), we will expect him to try to catch himself every time he feels one, to never find his emotions to be reasons for actions or for forming general reasoned judgments. If $\mathrm{Nicolas}$ says he is fighting his emotions, but often seems to be influenced by them in his actions and general judgments (he often gives in to the temptation to gossip, or to think his bosses are domineering, or to try to gain their approval), we may think he is not fighting them hard enough, and we may be inclined to hold him responsible. If his conduct and his general evaluations exhibit not a trace of being influenced by his emotions, if, despite his emotions, he is willing to challenge and criticize his bosses to their face when he believes it is justified, and he resists the temptation to gossip about them, then we may think that he is in no way responsible for his emotions, because the fact that they persist though he genuinely separates himself from them shows that he has no control over them. 82

The example of Nicolas's irrational emotions is appropriately analyzed in terms of the control Nicolas has over his emotions. But because the degree of control one has over emotions is too difficult to ascertain, it will be sufficient to determine the nature of Nicolas's attitude toward his emotions, since we know that he is in complete control of it.

The second example is a part of a story I get from Anthony Trollope.

Lucy Morris had been told by Lady Fawn, - in point of fact that, being a governess, she ought to give over falling in love with Frank Greystock, and she had not liked it. Lady Fawn no doubt had used words less abrupt,- had probably used but few words, and had expressed her meaning chiefly by little winks, and shakings of her head, and small gestures of her hands, and had ended by a kiss, - in all of which she had

82. I'm disagreeing with Robert Adams here. He seems to think any racist beliefs or reactions are bad no matter what el se is an aspect of the agent's character. My view is that he is just mistaken, that he confuses our just horror at most racist beliefs and emotions with an intuition that all agents are responsible for all of them. See R. Adams, “Involuntary Sins," Philosophical Review 94 (1985) : 3-31. 
intended to mingle mercy with justice, and had, in truth, been full of love. Nevertheless, Lucy had not liked it. No girl likes to be warned against falling in love, whether the warning be needed or not needed. In this case, Lucy knew very well that the caution was too late. It might be all very well for Lady Fawn to decide that her governess should not receive visits from her lover in her house;-and then the governess might decide whether, in those circumstances, she would remain or go away; but Lady Fawn could have no right to tell her governess not to be in love. All this Lucy said to herself over and over again, and yet she knew that Lady Fawn had treated her well. The old woman had kissed her, and purred over her, and praised her, and had really loved her. As a matter of course, Lucy was not entitled to have a lover. Lucy knew that well enough. As she walked alone among the shrubs, she made arguments in defense of Lady Fawn as against herself. And yet at every other minute, she would blaze up into a grand wrath, and picture to herself a scene in which she would tell Lady Fawn boldly that as her lover had been banished from Fawn Court, she, Lucy, would remain there no longer.83

If we analyze this passage in terms of a person's control over her emotions, we are likely to conclude that, as Lucy seems unable to control her anger despite her best efforts, she is not responsible for it. However, if we instead pay attention to the emotion's relations to Lucy's reasoning and deliberating, we will reach a different conclusion. Both Lucy's anger and Lucy's fight against her anger are products of reasoning. Her anger is dependent on the judgment that Lady Fawn is unjust to require Lucy not to fall in love. Her fight ( that is, her volition) against her anger is dependent on the judgment that Lady Fawn has always been just and good to her, and moreover, that she is correct in telling her that she ought not to have a lover. Thus, if we analyze Lucy's anger in accordance with Aquinas's view of reason-dependent emotions, we will conclude that though she is fighting against it unsuccesffully, Lucy is entirely responsible for her anger, because her anger is a symptom of her reasoned ambivalence.

Thus, the fact that Aquinas's account of our responsibility for our emotions is complicated and does not give us a single answer that can be applied mechanically to all cases seems to be a strength of his theory. Although his account does not explain in detail what emotions we are responsible for, it provides us with a principled way to make sense of and clarify our intuitions about our responsibility for emotions. It explains why sometimes we should think in terms of the control we have over our emotions and the attitude we have to them in order to determine whether we are responsible, while in cases where the emotion is reason-dependent, thinking in terms of control will yield no useful information about our responsibility for it.

83. Anthony Trollope, The Eustace Diamonds, chap. vii. 